\title{
Öğretmenler ve Okul Müdürleri Perspektifinden Okul Hesap Verebilirliği Politikaları*
}

\author{
DOI: $10.26466 /$ opus.292614
}

\author{
Coşkun Erdağg \\ * Yrd. Doç. Dr., Aksaray Üniversitesi Eğitim Fakültesi, Aksaray/Türkiye \\ E-Posta: coskunerdag79@gmail.comＯRCID: 0000-0002-6173-6340 \\ * Prof. Dr., Akdeniz Üniversitesi Eğitim Fakültesi, Antalya/Türkiye \\ E-Posta: engin.karadag@hotmail.com ORCID: $\underline{0000-0002-9723-3833}$
}

Öz

Batı kültüründe okul gelişimine yönelik ortaya çıan ve dünyaya yayılan hesap verebilirlik politikası son yıllarda Türk eğitim sisteminin de reform gündemine girmiştir. Yanlız, planlanan değiş̧imin başarısı hesap verebilirlik politikalarına ilişkin farklı görüş ve inançların farkında olunması ve bunlara uygun mekanizmaların üretilmesine bağlı olacaktır. Öğretmen ve yöneticilerin çeşitli hesap verebilirlik politikalarına ilişkin düşüncelerini belirlemeyi ve farklılaşmaları ortaya koymayı amaçlayan bu nedensel karşılaştırma çalışması; Kütahya ili ilköğretim, ilköğretim ve lise düzeyinde tabakalı örnekleme yöntemi ile rastgele belirlenen 357 öğretmen ve 154 yöneticinin Okul Hesap Verebilirlik Politikaları ölçeği aracılığıyla elde edilen görüşlerinin ne düzeyde olduğu, bunlaarın bazı bireysel ve kurumsal değiş̧kenlere göre farklılaşıp farklılaşmadığı sorularına cevap aramaktadır. Sonuç olarak, öğretmen ve okul yöneticileri öğretmen özerkliği, mesleki yeterlilik ve mesleki gelişimi amaçlayan güçlü politikalara ihtiyaç duyulduğu, performansla ilgili bilgi üretimine gerek olduğuna güçlü bir şekilde inanmaktadır. Öğretmen ve yöneticiler; velilerin hem idari hem de öğretim uygulamalarına ve karar verme süreçlerine katılımın desteklememekte; profesyonel hesap verme politikalarının okullardaki akademik performansı artırmanın en iyi yolu olduğunu inanmaktadırlar. Ayrıca; müdürler, özel okullarda görev yapan öğretmenler, erkek öğretmenler, fen ve anadolu liselerindeki öğretmenler diğer öğretmenlere kıyasla öğretmenlerin sonuçlardan sorumlu tutulması, kazanım değerlendirme sınavları, performans değerlendirme, ödül ve ceza mekanizmalarını içeren performans hesap verebilirlik politikasının gerekliliğine inanmaktadır.

Anahtar Kelimeler: Hesap verebilirlik, Kalite, Kontrol, Reform, Başarl, Performans, Okul

\footnotetext{
* Bu çalışma, Eskişehir Osmangazi Üniversitesi Eğitim Bilimleri Enstitüsü’nde Prof. Dr. Engin Karadağ danışmanlığında tamamlanan doktara tez çalışmasının kısmi bir parçası olarak hazırlanmış, 22-24 Kasım 2016 tarihlerinde Endonezya Malang'da düzenlenen "International Conference on Education"adlı uluslararası kongrede sözlü bildiri olarak sunulmuştur.
} 


\title{
School Accountability Policies: Teacher and Princi- pal Perspectives
}

DOI: 10.26466/opus.292614

\begin{abstract}
As a popular policy for school improvement in western culture, accountability for academic performance at schools is now in the reform agenda of Turkish educational system. Since developed in a different educational culture, it is important for the policymakers to be aware of the differences and similarities among Turkish teachers' beliefs in and views on the different accountability policies for higher academic achievement in core school subjects. Aiming to evaluate the thoughts of teaching staff on various accountability policies, this study of causal-comparative design revealed that, based on the data obtained from the stratified sample of 357 teachers and 154 administrators from the primary, elemantary and high schools in Kütahya, Turkey, via the Accountability Policies for Academic Performance questionnaire, the principals and teachers mostly agree with the need of teacher autonomy, professional qualification and professional development practices as well as the need for the generation of information about performance. While the teaching staff doesn't support the parents' participation both in administrative and instructional practices and decision making, they rather see professional accountability policies are the best for schools to increase academic performance. Additionally, those teachers; working as principal, male, teaching at private schools, and at schools with science program more support than other groups the performance accountability policy; the sum of teacher responsibility, student assessments, performance evaluations, rewards and punishment policies. Differently, all the teachers and principals strongly agree with the professional accountability policy; comprising teacher autonomy, teacher qualifications and professional development practices.
\end{abstract}

Key Words : Accountability, Quality, Control, School, Achievement, Performance 


\section{Giriş}

Modern zamanların beraberinde getirdiği küreselleşme, kapitalizm, teknolojik gelişmeler ve bilgi toplumu gerçekleri ülkeler ve kamu yönetimleri için birçok yeni problem üretmiştir. Ülkelerin gelişimi ve toplumların refahı insan sermayesinin niteliğine bağlanmış, eğitim sistemlerinden yeni nesillerin üretken bireyler olarak ülke ekonomik yaşamına katılımlarının sağlanması beklenmeye başlamıştır. Diğer taraftan, Türk eğitim sistemi hem YGS ve LYS gibi ulusal hem de PISA, TIMSS ve PIRLS gibi uluslararası değerlendirmelerde öğrenci akademik kazanımlarının istenen düzeyde olmamasından dolayı sıklıkla eleştirilmektedir (Aydın, Erdağ \& Taş, 2011; Aydın, Sarıer \& Uysal, 2012; Dinçer, 1998; EARGED, 2003; 2004; Eryılmaz, 1997; Göksu, 2002). Öğrencilerin akademik başarılarının artırılmasına amacıyla özellikle 1990‘lı yıllardan itibaren Milli Eğitimi Geliştirme Projesi (MGEP), okullarda Toplam Kalite Yönetimi (TKY) uygulaması, Müfredat Laboratuar Okulları, Temel Eğitime Destek Projesi (TEDP), Okul Performans Yönetim Modeli ve Planlı Okul Gelişim Modeli, Öğretmen yeterlilikleri gibi çeşitli girişimler uygulamaya konulmalarına rağmen arzu edilen sonuçların üretilmesinde etkisiz kalınmıştır (MEB, 2002; 2009, Akt. Kantos, 2010). Son yıllarda ise, özellikle 2001'de yaşanan ekonomik kriz sonrası Türkiye'de Dünya Bankası ve IMF gibi uluslararası kuruluşların telkinleri ile yönetimlerin yeniden yapılandırılması, yerelleşme, hizmet üretimi ve sunumu vatandaşlar seviyesine indirilmesi, demokrasinin bir gereği olarak vatandaşlar ile devlet arasında hesap sorma ve hesap verme mekanizmaları kurulması, böylece kamu kurumlarının hem mali performanslarının hem de hizmet performanslarının kontrolünün sağlanması gündeme gelmiştir (Akçakaya \& Yücel, 2009; Balcı, 2003; Bilgiç, 2008; Kızıltaş, 2005). Eğitim harcamalarını ve düşük öğrenci başarısını eğitim sisteminin ürettiği temel problemler olarak gören "yeni kamu yönetimi" anlayışı, çözümü daha hesap verebilir okullarda aramaktadır. Özellikle Anglo-sakson ülkelerde ortaya çıan 
hesap verebilirlik akımı ile, okullar üzerinde farklı kontrol mekanizmaları geliştirilmiş, böylece okullarda arzu edilen akademik performans artı̧̧1 sağlanmaya çalışılmaktadır (Kuchapski, 2001; Levin, 1994; McEwen, 1995; Sullivan, 1973, Akt. McNelis, 1998, s. 12).

Alanyazın incelendiğinde, günümüzde kaliteli eğitim hizmeti ve yüksek öğrenci performansı için yüksek kapasiteye sahip okullara, okul kapasitesinin geliştirilmesi için de okul üzerinde kurulacak dış performans baskısına ihtiyaç duyulduğunu savunan hesap verebilirlik politikalarının birçok diş güç odağı belirlediği, bu odaklar ile okullar arasında hesap sorma ve verme sürecini içeren sosyal mekanizmalar ürettiği görülmektedir. Bu bağlamda kimin, kime, hangi konuda, hangi sonuçlarla ve nasıl açıklama yapacağı, kendini savunarak eylemlerini nasıl haklı çıkaracağını kapsayan sosyal bir süreç oluşturulmaktadır. Oluşturulna farklı dış güç odaklarıyla okullar üzerinde politik, yasal, bürokratik, performans, piyasa ve profesyonel olmak üzere farklı hesap verebilirlik mekanizmaları oluşturulmuştur (Adams \& Kirst, 1999; Darling-Hammond, 1989; Darling-Hammond \& Ascher, 1991; Heim, 1995; Kuchapski, 2001; Stecher \& Kirby, 2004; Wagner, 1989). Bunlardan bürokratik ve performans hesap verebilirliği okullar üzerinde üst yönetimlerin, piyasa hesap verebilirliği veli ve öğrencilerin, profesyonel hesap verebilirlik ise öğretmenlerin güçlendirilmesini içeren sosyal mekanizmalarıyla öğrenci kazanım düzeylerinin artırılmasını hedeflemektedir.

Bürokratik hesap verebilirlik modeli, ödüllendirme ve cezalandırma yetkisine sahip üst yönetimlerin kendi tercih ve kararlarına göre eğitim hizmetlerine ilişkin okullarda neyin nasıl yapılacağına ilişkin standartları ve kuralları belirlediği, okulların ise girdi ve süreçlerinin etkili bir şekilde işletilmesinden sorumlu tutulduğu, üst yönetimin belirlediği hedefleri ve kuralları benimseyerek tam olarak yerine getirmeye çalıştığı, davranışlarına göre ödüllendirildiği veya cezalandırıldığı hiyerarşik yapıya dayalı bir hesap sorma ve verme mekanizmasını ifade etmektedir (Adams \& Kirst, 1999; Bovens, 2010; Darling-Hammond, 1990; O’Day, 2002). 
Performans hesap verebilirliği modeli standartı yüksek matematik ve okuma becerileri öğretim programlarının geliştirilmesi, belirli standartlar ve amaçlara göre oluşturulan standart sınavlar ile öğrenci başarısının belirlenmesi ve izlenmesi, sınav sonuçları 1şığında yapılan öğrenci ve okul başarı değerlendirmelerinin velilere ve topluma bilgi olarak sunumu, okulların öğrencilere kazandırdıkları başarıya göre ödül ve cezalarla motivasyonunun artırılması, öğretmen yetiştirme ve geliştirme konusunda standartların belirlenmesini kapsamaktadır (Spencer, 2006). Diğer taraftan, az maliyetle arzu edilen eğitim sonuçlarının üretilmesini sağlayacak öğretmen performans sözleşmeleri, performansa göre ödeme sistemi gibi araçları kapsayan öğretmen teşvik sistemleri uygulamaya konulmuştur (Bruns, Filmer \& Patronas, 2011; Fuhrman, 1999; Mintrop, 2002).

Piyasa hesap verebilirliği modeli, okul yönetiminin ve kontrolünün toplumla paylaşılması, merkezi disiplin düzenlemelerinin kaldırılarak okuldaki program, bütçe ve personel konularında yerel topluma ve okula gerekli yetkilerin devredilmesini, başarının artırılmasında ev ve çevre faktörlerinden yararlanılmasını savunmaktadır. $\mathrm{Bu}$ model velilere okul seçme olanağı sağlamakta, memnuniyetsizlik halinde öğrenciyi başka bir okula nakledebilmeleri, öğretim programı, bütçe ve personel konuları ile öğretim süreçlerinde seslerini duyurabilme ve okul karar alma süreçlerine katılım hakkı getirmektedir. Öte taraftan, okulları düzenleyen kurallar kaldırılarak okulların serbest piyasa koşulları içerisinde kendi problemlerine kendilerinin çözüm bulması beklenmektedir. Bu kapsamda, bir taraftan özel eğitim hizmetinin verildiği sözleşmeli ve mıknatıs okulların açılması, öğrenci başına kupon (voucher) uygulaması ve vergi desteği gibi rekabetçi finans sisteminin faaliyete geçirilmesi sağlanırken, diğer taraftan da, okulların uyguladıkları programların tanitımı ve performans sonuçlarının ilanıyla veli ve öğrencilerin ikna edilmesini böylece öğrenciyle beraber gelen finansmanı okula kazandıran mekanizmalar kullanılmaktadır (Bruns, Filmer \& Patronas, 2011; Chavkin \& Williams, 1987, Akt. Parker \& Leithwood, 2000; Hill, 1996; Kuchapski, 2001; 
Leithwood \& Earl, 2000; Spencer, 2006).

Profesyonel hesap verebilirlik modeli, fazla karışık ve teknik olan eğitim öğretim sürecinin bürokratik kurallar ve düzenlemeler vasitasıyla yönetilemeyeceği, bunun yerine yüksek alan ve mesleki becerilere sahip donanımlı öğretmenlere uygun yetki ve destek sağlandığında öğrencilerin başarısının artacağını savunmakta, bu kapsamda öğretmenlerin mesleki yeterliliği ve mesleki özerkliğine vurgu yapmaktadır. Yüksek alan ve mesleki bilgiye sahip öğretmenlerin sistemde yer alabilmesi için öğretmenlik mesleği standartlarının geliştirilmesi ve uygulanmasının zorunlu olduğu savunulmaktadır. Diğer yandan, yetenekli ve becerikli öğretmenlerin mesleği icraları esnasında öğretime ilişkin problemleri belirlemesi ve çözüm yollarını tartışarak kendi kararlarını alma, bunları velilere, topluma ve yönetim kurullarına açıklama yaparak ve savunarak uygulama yetkisinin verilmesi, böylelikle çalışma ortamının hiyerarşiden uzaklaştırılması amaçlanmaktadır. Ayrıca, bütçe, öğretim programı ve öğretmenler ile ilgili kritik kararlarda öğretmenlerin mesleki bilgisinden daha çok yararlanılması, öğretmenlik uygulamalarında desteklenmeleri ve öğretmenler arası işbirliğinin geliştirilmesi beklenmektedir (Bruns, Filmer \& Patronas, 2011; Darling-Hammond, 1985; Hess, 1991; Kuchapski, 2001; Leithwood \& Earl, 2000; O`Day, 2002; Ranson, 2003).

Bu çalışmada, okul geliştirmeye dönük hesap verebilirlik politikalarına temel teşkil eden varsayımlara ilişkin öğretmen ve okul yöneticilerinin görüşlerinin ortaya konulması, görüşler arasındaki farklılıkların muhtemel bireysel ve kurumsal nedenlerinin ortaya konulması amaçlanmaktadır. Bu kapsamda (i) öğretmen ve okul yöneticilerinin bürokratik, performans, piyasa ve profesyonel hesap verebilirlik politikalarının varsayımlarına katılım düzeylerinin hangi düzeyde olduğu, (ii) görüşlerinin kurumsal (okul tipi, okul türü) ve bireysel (cinsiyet, görev, branş, sendika) özelliklerine göre farklılaşıp farklılaşmadı̆̆ı sorularına cevap aranmaktadir. 


\section{Yöntem}

Bu araştırmada, akademik başarının artırılmasına yönelik okul yöneticileri ve öğretmenlerinin hesap verebilirlik politikalarına ilişkin görüşlerinin bireysel ve görev yeri özelliklerine göre farklılaşma durumunu incelemek ve muhtemel nedenlerini belirlemek amaciyla nedensel-karşılaştırma deseni kullanılmıştır.

\section{Evren ve Örneklem}

Araştırmanın evreni, 2012-2013 öğretim yılında Kütahya ili merkez ilçesi sinırlarındaki kamu ve özel ilkokul, ortaokul ve liselerde görev yapan 242 'si okul yöneticisi ve 2310'u öğretmen olmak üzere toplam 2552 kişiden oluşmaktadır. Araştırmanın örneklemi tabakalı örnekleme yöntemi kullanılarak rastgele yöntemle belirlenmiştir. Milli Eğitim Bakanlığı Eğitim Bölgeleri ve Eğitim Kurulları Yönergesi (1999) kapsamında Kütahya İl Milli Eğitim Müdürlüğü tüm merkez okullarını üç tabakaya ayırmış, bu kapsamda, her eğitim tabakasında yer alan okullar öncelikle türlerine göre (i) birleştirilmiş sınıflı ilkokullar, (ii) ilkokullar, (iii) ortaokullar, (iv) genel liseler, $(v)$ anadolu ve fen liseleri, (vi) meslek liseleri olmak üzere alt kümelere ayrılmıştır. Örneklemi oluşturacak okullar kendi okul tabakaları ve kümeleri arasından evren büyüklüğüyle orantısal olarak kendi içinde yeterli örneklem büyüklügüne ulaşıncaya kadar rassal olarak belirlenmiştir. Örnekleme işlemi sonucu 357 öğretmen ve 154 okul yöneticisi çalışmaya dahil edilmiştir.

\section{Veri Toplama Araçları}

Çalışmada öğrencilerin akademik performansın artırılmasına olanak sağlayacak hesap verebilirlik politikalarına ilişkin öğretmen ve okul yöneticilerinin düşüncelerini ölçmek amaciyla Okul Hesap Verebilirlik 
Mekanizmaları Ölçeği kullanılmıştır. Ölçek, Bradshaw (2003) ve Too'nun (1989) çalışmaları temel alınarak, ilgili okul hesap verebilirliğine ilişkin literatür değerlendirmesi sonucu araştırmacı tarafından otuzyedi maddeden oluşturulmuştur. Maddelerin oluşturulmasında eğitimde hesap verebilirlik politikaları, okullarda öğrencilerin akademik başarı düzeylerinin artırılması hedefine yönelik motivasyonu artırmayı amaçlayan dış kaynaklı kontrol ve baskı mekanizmaları olarak tanımlanmıştır. Örneklem tepkileri kesinlikle katılmıyorum (1) ve kesinlikle katıliyorum (5) arası cevaplama skalası olmak üzere 5'li Likert tipinde değerlendirilmiştir. Taslak ölçeğin yapı geçerliği (i) açımlayıcı faktör analizi ve (ii) doğrulayıcı faktör analizi olarak üzere iki aşamada gerçekleştirilmiştir. Bu aşamada öncelikle 511 okul yöneticisi ve öğretmen grubundan elde edilen veriler rassal olarak ikiye ayrılmıştır. İlk 256 birim veri üzerinde açımlayıc faktör analizi, diğer 255 birim üzerinde ise doğrulayıcı faktör analizi işlemleri yürütülmüştür. Taslak ölçeğin KaiserMeyerOlkin=.89 ve Bartlett $[\mathrm{p}<.01]$ test analizleri sonuçlarına dayanılarak çok faktörlü muhtemel yapısından dolayı Varimax dik eksen döndürme tekniği kullanılarak (Kline, 1994; Rennie, 1997; Stapleton, 1997; Stevens, 1996) açımlayıcı faktör analizi gerçekleştirilmiş, analiz sonucunda ölçeğin otuzyedi maddesinin öz değeri 1'den büyük onbir alt ölçek oluşmuştur. Ölçeğin alt ölçeklerdeki öz değer toplamı 22.16 ve açıklanan varyans yüzdesi toplamı $59.89^{\prime}$ dur. Alt ölçek maddelerinin faktör yükleri ise 0.36 ile 0.76 arasında değişmektedir. Ölçeğin yapı geçerliği için yapılan doğrulayıcı faktör analizi sonucunda ise, düşük Ki-kare $(\chi 2)$ değeri [ $\chi 2=926.18, \mathrm{df}=542, \mathrm{p}<.01]$ ve diğer uyum iyiliği indeksleri de [GFI=0.90, AGFI=0.89, PGFI=0.91, RMSEA=0.07, CFI=0.90] ölçek için önerilen modelin uygun olduğu, modellenen faktör yapısının doğruladığını göstermektedir. Ölçeğin güvenirliği, iç tutarlılık yöntemiyle incelenmiştir. Ölçeğin Cronbach Alpha iç tutarlılık katsayısı 0.71 ile 0.91 arasında değişmektedir. Sonuç olarak ölçek, Profesyonel Hesap Verebilirlik (Mesleki Gelişim [8 madde, $\alpha=$.91], Öğretmen Otonomisi [2 madde, $\alpha=.79$ ], 
Mesleki Yeterlilikler [2 madde, $\alpha=.77]$ ), Performans Hesap Verebilirliği (Öğrenci Kazanım Değerlendirmeleri [2 madde, $\alpha=.75$ ], Performans Değerlendirmeleri [ 3 madde, $\alpha=.77$ ], Sorumluluk ve Ödül [ 4 madde, $\alpha=$ .82], Ceza ve Yaptırımlar [5 madde, $\alpha=.85$ ]), Piyasa Hesap Verebilirliği (Katılım [5 madde, $\alpha=.81$ ], Akademik standartlar [2 madde, $\alpha=.76$ ], Bilgi [2 madde, $\alpha=.75]$ ), Bürokratik Hesap Verebilirlik (Mevzuata Uyma [2 madde, $\alpha=.74]$ ) politikaları olmak üzere dört bileşen ve on bir alt ölçek olarak düzenlenmiştir. Bunlar:

(i) Mesleki Gelişim: Bu alt ölçekten alınan yüksek puan, hem yöneticilerin hem de öğretmenlerin görevlerine ilişkin alan, pedagoji ve yöneticilik niteliklerini artırmaya yönelik öğrenme ortamlarını ve uygulamalarını desteklediklerinin göstergesidir.

(ii) Öğretmen Otonomisi: Bu alt ölçekten alınan yüksek puan, öğretim süreçlerinin ve programlarının planlanması ve yürütülmesinin öğretmenlerin uzmanlıklarına ve takdirlerine bırakılması ile öğretim süreçlerinde öğretmenlerin güçlendirilmesi yönündeki uygulamalara destek verildiğini göstermektedir.

(iii) Mesleki Yeterlilikler: Bu alt ölçekten alınan yüksek puan, okul yöneticilerinin ve öğretmenlerin görev alanlarında ve öğretim yöntem ve teknikleri konusunda yeterli bilgi ve beceriye sahip olduklarını göstermeleri gerektiği düşüncesinin desteklendiğini göstermektedir.

(iv) Öğrenci Kazanım Değerlendirmeleri: Bu alt ölçekten alınan yüksek puan, okulların öğretim süreçleriyle öğrencilere kazandırdıkları kazanımların izlenmesi, kazanım seviyelerinin tespit edilmesi, öğrencilerin akademik performanslarının ortaya çıkartılması ve karşılaştırmalı olarak değerlendirilmesi gibi uygulamaların desteklendiğini göstermektedir.

(v) Performans Değerlendirmeleri: Bu alt ölçekten alınan yüksek puan, öğretmenlerin öğrencilere kazandırdıkları akademik başarı düzeyine ilişkin üst yönetime rapor verilmesi, öğretmenlerin öğrencilerin akad- 
emik gelişimine göre okul müdürü tarafından değerlendirilmesi uygulamasına destek verildiğini göstermektedir.

(vi) Sorumluluk ve Ödül: Bu alt ölçekten alınan yüksek puan, öğrencilerin akademik başarısının artırılması konusunda öğretmenlerin sorumlu olduğu düşüncesine ve öğrencilerin akademik başarısını artıran öğretmen ve okulların ödüllendirilmesi uygulamasına destek verildiğini göstermektedir.

(vii) Ceza ve Yaptırımlar: Bu alt ölçekten alınan yükssek puan, öğrencilerin akademik başarısını artırma konusunda düşük performans gösteren okul yöneticileri ve öğretmenlere öncelikle akademik performansın artırılmasına yönelik gelişim desteğinin sağlanması, sonrasında düşük performans göstermeye devam eden öğretmenlere ve okul yöneticilerine çeşitli ceza ve yaptırımlar uygulanması görüşünün desteklediğini göstermektedir.

(viii) Katılım: Bu alt ölçekten alınan yüksek puan, öğretim programlarının hazırlanmasında velilerin tercihlerinin dikkate alınması, öğretim etkinliklerini gözlemleme ve etkinliklere katılımcı olma konusunda velilere imkan sağlanması, okulun yönetimine ilişkin kararlarda ise veli ve öğrencilere daha çok söz hakkının verilmesini içeren uygulamaların desteklendiğini göstermektedir.

(ix) Akademik Standartlar: Bu alt ölçekten alınan yüksek puan, okullar üzerinde öğrencilerin akademik başarısının artırılmasına yönelik oluşan veli, vatandaşlar ve üst yönetim birimleri kaynaklı dışsal beklentilerin ve standartların öğretmenleri sorumlu kılacağı, okulları bu standartların karşılanması konusunda gerekli çalışma süreci içerisine sokacağ 1 düşüncesinin desteklendiğini göstermektedir.

(x) Bilgi: Bu alt ölçekten alınan yüksek puan, öğrencilerin akademik performansları ve olumsuz performans nedenlerine ilişkin bilgi üretilmesi, üretilen performans bilgisinin velilere ve kamuoyuna sunulması düşüncesinin ve uygulamalarının desteklendiğini göstermektedir. Bu faktöre ilişkin örnek maddeler aşağıdaki gibidir: 
(xi) Mevzuata Uyma: Bu alt ölçekten alınan yüksek puan, öğretim süreçlerinin üst yönetim birimlerince oluşturulan ve uygulamaya konulan yasal mevzuat, kurallar ve talimatların izin verdiği bir çerçeve içerisinde yürütülmesi gerektiği düşüncesi ve uygulamasına destek verildiğini göstermektedir.

\section{İșlem}

Öğretmen ve okul yöneticilerinin hesap verebilirlik politikalarına ilişkin düşüncelerinin bazı demografik ve görev değişkenlerine göre farklılaşma düzeyini belirlemek için yürütülen bu çalışma üç aşamada gerçekleşmiştir.

(i) Araştırmada istatistiksel çözümlemelere geçilmeden önce, demografik değişkenler gruplandırılmış, bunun ardından uygulanan veri toplama aracı 5'li Likert sistemiyle puanlandırılmıştır.

(ii) Araştırma grubunu oluşturan okul yöneticilerinin ve öğretmenlerin demografik özelliklerini belirleyici frekans $(n)$ ve yüzde $(\%)$ değerleri çıkarılarak ölçeklerin tüm alt ölçek puanları için ortalama (X) ve standart sapma (SS) puanları hesaplanmıştır.

(iii) Okul yöneticilerinin ve öğretmenlerin alt ölçek puanlarının çeşitli demografik değişkenlere göre test etmeden önce araştırma verilerinin normal dağılım özelliği taşıyıp taşımadıkları tek örneklem Kolmogorov-Smirnov Testi ile analiz edilmiş, sonucunda da dağılımların normal dağıldığı saptanmıştır [ $p>0.05]$. Buna göre, dağılımlarının analizinde parametrik analiz teknikleri kullanılmıştır. Bu kapsamda;

- Örneklem grubunu oluşturan okul yöneticilerinin ve öğretmenlerin alt ölçek puanlarının; cinsiyet ve okul tipi değişkenlerine göre farklılaşıp farklılaşmadığını belirlemek için bă̆ımsız gruplar t-testi; 
- Örneklem grubunu oluşturan okul yöneticilerinin ve öğretmenlerinin alt ölçek puanlarının; görev, branş, okul kademesi ve sendika değişkenlerine göre farklılaşıp farklılaşmadığını belirlemek için ANOVA;

- ANOVA sonrasinda elde edilen farkın hangi gruplar arasında olduğunu belirlemek için Scheffe testi kullanılmıştır.

\section{Bulgular}

\section{Hesap Verebilirlik Politikaları Ölçeğine İlişkin Genel Bulgular}

Okul yöneticileri ve öğretmenlerin Hesap Verebilirlik Politikaları Ölçeğine ait alt ölçek puanlarına ilişkin ortalama ve standart sapma değerleri Tablo 1 'de sunulmuştur. Okul yöneticileri ve öğretmenlerin hesap verebilirlik politikalarına ilişkin görüşlerini ifade eden puanların aritmetik ortalamaları 2.42 ile 4.15 arasında değişmektedir. Eğitim personeli hesap verebilirlik politikalarının gerekliliğini en yüksek ortalama ile mesleki gelişim alt ölçeğinde değerlendirirken, en düşük ortalamayla ceza ve yaptırımlar alt ölçeğinde değerlendirmiştir.

Tablo 1: Hesap Verebilirlik Politikalarn Alt Ölçeklerinin $N, X$ ve SS Değerleri

\begin{tabular}{lccc}
\hline Alt Ölçekler & $N$ & $X$ & $S S$ \\
\hline 1-Mesleki Gelişim & 511 & 4.15 & .52 \\
2-Ceza ve Yaptırımlar & 511 & 2.42 & .82 \\
3-Sorumluluk ve Ödül & 511 & 3.81 & .64 \\
4-Katılım & 511 & 2.97 & .68 \\
5-Öğretmen Otonomisi & 511 & 3.77 & .77 \\
6-Bilgi & 511 & 3.99 & .70 \\
7-Akademik Standartlar & 511 & 3.11 & .80 \\
8-Öğrenci Kazanım Değerlendirmeleri & 511 & 3.79 & .79 \\
9-Performans Değerlendirmeleri & 511 & 3.31 & .66 \\
10-Mevzuata Uyma & 511 & 3.10 & .85 \\
11-Mesleki Yeterlilikler & 511 & 3.79 & .79 \\
\hline
\end{tabular}


Okul yöneticileri ve öğretmenlerin Hesap Verebilirlik Politikaları Ölçeğinin bileşenlerine vermiş oldukları puanlara ilişkin ortalama ve standart sapma değerleri Tablo 2'de sunulmuştur. Okul yöneticileri ve öğretmenlerin hesap verebilirlik politikaları bileşenlerine ilişkin görüşlerini ifade eden puanların aritmetik ortalamaları 3.10 ile 3.90 arasında değişmektedir. Bununla birlikte, hesap verebilirlik politikalarının gerekliliği en yüksek ortalama ile profesyonel hesap verebilirlik politikaları bileșeninde değerlendirilirken, en düşük ortalamayla bürokratik hesap verebilirlik politikaları bileşeninde değerlendirilmiştir.

Tablo 2: Hesap Verebilirlik Politikaları Ölçeği Bileşenlerine İlişkin N, X ve SS

Değerleri

\begin{tabular}{lrrr}
\hline Bileşenler & $\boldsymbol{N}$ & $\boldsymbol{X}$ & SS \\
\hline 1-Profesyonel Hesap Verebilirlik Politikaları & 511 & 3.90 & .51 \\
2-Performans Hesap Verebilirliği Politikaları & 511 & 3.24 & .49 \\
3-Piyasa Hesap Verebilirliği Politikaları & 511 & 3.36 & .49 \\
4-Bürokratik Hesap Verebilirlik Politikaları & 511 & 3.10 & .85 \\
\hline
\end{tabular}

\section{Hesap verebilirlik Politikaları Alt Ölçek Puanlarının Bireysel ve Ku- rumsal Değişkenler Açısından Değerlendirilmesi.}

Tablo 3'te verilen Hesap Verebilirlik Politikaları Ölçeği puanlarının cinsiyet değişkenine göre anlamlı bir farklılık gösterip göstermediğini belirlemek amacıyla gerçekleştirilen bağımsız gruplar t-testi sonuçlarına göre, hesap verebilirlik politikaları ve uygulamalarına ilişkin görüşlerin mesleki gelişim, sorumluluk ve ödül, öğretmen otonomisi, bilgi, akademik başarı beklentisi, mevzuata uyma alt ölçeklerinde cinsiyet değişkenine göre anlamlı bir farklılık saptanmazken [p>.05]; ceza ve yaptırımlar, katılım, öğrenci kazanım değerlendirmeleri, performans değerlendirmeleri, mesleki yeterlilikleri alt ölçeklerinde erkek okul yöneticileri ve öğretmenler lehine anlamlı bir farklılık saptanmıştır $[\mathrm{p}<.05]$. 
Tablo 3: Hesap Verebilirlik Politikaları Alt Ölçek Puanlarının Cinsiyet Değişkenine Göre t-Testi Sonuçlan

\begin{tabular}{|c|c|c|c|c|c|c|}
\hline Alt Ölçekler & Cinsiyet & $N$ & $X$ & $S S$ & $t$ & $P$ \\
\hline \multirow{2}{*}{ 1-Mesleki Gelişim } & Erkek & 351 & 4.16 & .51 & \multirow{2}{*}{1.13} & \multirow{2}{*}{.25} \\
\hline & Kadın & 150 & 4.10 & .55 & & \\
\hline \multirow{2}{*}{ 2-Ceza ve Yaptırımlar } & Erkek & 351 & 2.51 & .83 & \multirow{2}{*}{3.89} & \multirow{2}{*}{.00} \\
\hline & Kadın & 150 & 2.20 & .75 & & \\
\hline \multirow{2}{*}{ 3-Sorumluluk ve Ödül } & Erkek & 351 & 3.81 & .65 & \multirow{2}{*}{.88} & \multirow{2}{*}{.37} \\
\hline & Kadın & 150 & 3.76 & .62 & & \\
\hline \multirow{2}{*}{ 4-Katılım } & Erkek & 351 & 3.07 & .66 & \multirow{2}{*}{5.10} & \multirow{2}{*}{.00} \\
\hline & Kadın & 150 & 2.73 & .67 & & \\
\hline \multirow{2}{*}{ 5-Öğretmen Otonomisi } & Erkek & 351 & 3.78 & .77 & \multirow{2}{*}{.05} & \multirow{2}{*}{.95} \\
\hline & Kadın & 150 & 3.77 & .75 & & \\
\hline \multirow{2}{*}{ 6-Bilgi } & Erkek & 351 & 3.96 & .70 & \multirow{2}{*}{-1.26} & \multirow{2}{*}{.20} \\
\hline & Kadın & 150 & 4.04 & .68 & & \\
\hline \multirow{2}{*}{ 7-Akademik Standartlar } & Erkek & 351 & 3.13 & .79 & \multirow{2}{*}{1.26} & \multirow{2}{*}{.20} \\
\hline & Kadın & 150 & 3.03 & .83 & & \\
\hline \multirow{2}{*}{$\begin{array}{l}\text { 8-Öğrenci Kazanım Değer- } \\
\text { lendirmeleri }\end{array}$} & Erkek & 351 & 3.85 & .76 & \multirow{2}{*}{2.39} & \multirow{2}{*}{.01} \\
\hline & Kadın & 150 & 3.66 & .83 & & \\
\hline \multirow{2}{*}{$\begin{array}{l}\text { 9-Performans Değerlendir- } \\
\text { meleri }\end{array}$} & Erkek & 351 & 3.37 & .66 & \multirow{2}{*}{3.73} & \multirow{2}{*}{.00} \\
\hline & Kadın & 150 & 3.13 & .67 & & \\
\hline \multirow{2}{*}{ 10-Mevzuata Uyma } & Erkek & 351 & 3.12 & .89 & \multirow{2}{*}{.75} & \multirow{2}{*}{.44} \\
\hline & Kadın & 150 & 3.06 & .77 & & \\
\hline \multirow{2}{*}{ 11-Mesleki Yeterlilikler } & Erkek & 351 & 3.85 & .76 & \multirow{2}{*}{2.39} & \multirow{2}{*}{.01} \\
\hline & Kadın & 150 & 3.66 & .83 & & \\
\hline$S D=499$ & & & & & & \\
\hline
\end{tabular}

Tablo 4'te verilen Hesap Verebilirlik Politikaları ölçek puanlarının görev değişkenine göre anlamlı bir farklılık gösterip göstermediğini belirlemek amacıyla gerçekleştirilen tek yönlü varyans analizi sonuçlarına göre, okul yöneticileri ve öğretmenlerin hesap verebilirlik politikalarına ilişkin görüşlerinde sorumluluk ve ödül, öğretmen otonomisi, bilgi, akademik standartlar alt ölçeklerinde okullarındaki görevlerine göre anlamlı bir farklılık saptanmazken [p>.05]; mesleki gelişim [F=6.84; $p<.05]$, ceza ve yaptırımlar [F=25.04; $p<.05]$, katılım [F=10.56; $p<.05]$, öğrenci kazanım değerlendirmeleri $[F=4.08 ; p<.05]$, performans değerlendirmeleri $[F=17.46 ; p<.05]$, mesleki yeterlilikler $[F=4.08 ; p<.05]$ alt ölçeklerinde anlamlı bir farklılık 
saptanmıştır. ANOVA sonrası Levene's testi ile grup dağılımlarının varyanslarının homojen olduğu saptanmıştır [p>.05]. Buna göre, Scheffe çoklu karşılaştırma analizi sonucu mesleki gelişim, ceza ve yaptırımlar, katılım, öğrenci kazanım değerlendirmeleri, performans değerlendirmeleri ve mesleki yeterlilikler puanlarının görev değişkeni okul müdürü grubuyla öğretmen grubu arasında okul müdürü grubu lehine istatistiksel olarak $[p<.05]$ düzeyinde anlamlı bir farklılık saptanmıştır. Aynı zamanda, ceza ve yaptırımlar, katılım ve performans değerlendirme ölçek puanlarının görev değişkeni müdür yardımcısı grubuyla öğretmen grubu arasında müdür yardımcısı grubu lehine istatistiksel olarak [ $p<.05]$ düzeyinde anlamlı bir farklılık saptanmıştır.

Tablo 4: Hesap Verebilirlik Politikaları Alt Ölçek Puanlarının Görev Değişkenine Göre Tek Yönlï Varyans Analizi (ANOVA) Sonuçları

\begin{tabular}{|c|c|c|c|c|c|c|c|c|c|c|}
\hline \multirow[b]{2}{*}{ Alt Ölçek } & \multirow[b]{2}{*}{ Görev } & \multicolumn{4}{|c|}{$N, X$ ve SS Değerleri } & \multicolumn{3}{|c|}{ ANOVA Sonuçları } & \multirow[b]{2}{*}{$\mathbf{F}$} & \multirow[b]{2}{*}{$\mathrm{p}$} \\
\hline & & $N$ & $X$ & SS & Var. K. & K.T. & SD & K.O. & & \\
\hline \multirow{4}{*}{$\begin{array}{l}\text { 1-Mesleki } \\
\text { Gelişim }\end{array}$} & Müdür & 51 & 4.38 & .43 & G. Aras1 & 3.68 & 2 & 1.84 & 6.84 & .00 \\
\hline & M. Yard. & 103 & 4.19 & .50 & G. İçi & 136.93 & 508 & .27 & & \\
\hline & Öğretmen & 357 & 4.10 & .53 & Toplam & 140.62 & 510 & & & \\
\hline & Toplam & 511 & 4.15 & .52 & & & & & & \\
\hline \multirow{4}{*}{$\begin{array}{l}\text { 2-Ceza ve } \\
\text { Yaptırımlar }\end{array}$} & Müdür & 51 & 2.94 & .85 & G. Aras1 & 31.07 & 2 & 15.53 & 25.04 & .00 \\
\hline & M. Yard. & 103 & 2.70 & .79 & G. İçi & 315.12 & 508 & .62 & & \\
\hline & Öğretmen & 357 & 2.26 & .77 & Toplam & 346.20 & 510 & & & \\
\hline & Toplam & 511 & 2.42 & .82 & & & & & & \\
\hline \multirow{4}{*}{$\begin{array}{l}\text { 3-Sorumlu- } \\
\text { luk ve Ödül }\end{array}$} & Müdür & 51 & 3.91 & .68 & G. Arası & .67 & 2 & .33 & .80 & .44 \\
\hline & M. Yard. & 103 & 3.82 & .63 & G. İçi & 213.18 & 508 & .42 & & \\
\hline & Öğretmen & 357 & 3.79 & .64 & Toplam & 213.85 & 510 & & & \\
\hline & Toplam & 511 & 3.81 & .64 & & & & & & \\
\hline \multirow{4}{*}{ 4-Katılım } & Müdür & 51 & 3.21 & .62 & G. Arası & 9.45 & 2 & 4.72 & 10.56 & .00 \\
\hline & M. Yard. & 103 & 3.16 & .61 & G. İçi & 227.17 & 508 & .44 & & \\
\hline & Öğretmen & 357 & 2.88 & .68 & Toplam & 236.62 & 510 & & & \\
\hline & Toplam & 511 & 2.97 & .68 & & & & & & \\
\hline \multirow{4}{*}{$\begin{array}{l}\text { 5-Öğretmen } \\
\text { Otonomisi }\end{array}$} & Müdür & 51 & 3.79 & .81 & G. Arası & .29 & 2 & .14 & .24 & .78 \\
\hline & M. Yard. & 103 & 3.72 & .75 & G. İçi & 305.94 & 508 & .60 & & \\
\hline & Öğretmen & 357 & 3.78 & .77 & Toplam & 306.24 & 510 & & & \\
\hline & Toplam & 511 & 3.37 & .77 & & & & & & \\
\hline \multirow{4}{*}{ 6-Bilgi } & Müdür & 51 & 4.02 & .72 & G. Arası & .23 & 2 & .11 & .24 & .78 \\
\hline & M. Yard. & 103 & 4.02 & .63 & G. İçi & 249.79 & 508 & .49 & & \\
\hline & Öğretmen & 357 & 3.98 & .71 & Toplam & 250.03 & 510 & & & \\
\hline & Toplam & 511 & 3.99 & .70 & & & & & & \\
\hline
\end{tabular}




\begin{tabular}{|c|c|c|c|c|c|c|c|c|c|c|}
\hline & Müdür & 51 & 3.15 & .71 & G. Aras1 & .15 & 2 & .07 & .11 & .88 \\
\hline 7-Akademik & M. Yard. & 103 & 3.08 & .72 & G. İçi & 333.62 & 508 & .65 & & \\
\hline \multirow[t]{2}{*}{ Standartlar } & Öğretmen & 357 & 3.11 & .84 & Toplam & 333.78 & 510 & & & \\
\hline & Toplam & 511 & 3.11 & .80 & & & & & & \\
\hline 8-Öğrenci & Müdür & 51 & 4.09 & .68 & G. Arası & 5.06 & 2 & 2.53 & 4.08 & .01 \\
\hline Kazanım & M. Yard. & 103 & 3.79 & .79 & G. İçi & 315.06 & 508 & .62 & & \\
\hline \multirow{2}{*}{$\begin{array}{l}\text { Değerlendir- } \\
\text { meleri }\end{array}$} & Öğretmen & 357 & 3.75 & .79 & Toplam & 320.13 & 510 & & & \\
\hline & Toplam & 511 & 3.79 & .79 & & & & & & \\
\hline \multirow{4}{*}{$\begin{array}{l}\text { 9-Performan } \\
\text { Değerlendir- } \\
\text { meleri }\end{array}$} & Müdür & 51 & 3.66 & .63 & G. Aras1 & 14.68 & 2 & 7.34 & 17.46 & .00 \\
\hline & s $\mathrm{M}$. Yard. & 103 & 3.51 & .61 & G. İçi & 213.56 & 508 & .42 & & \\
\hline & Öğretmen & 357 & 3.20 & .65 & Toplam & 228.25 & 510 & & & \\
\hline & Toplam & 511 & 3.31 & .66 & & & & & & \\
\hline \multirow{4}{*}{$\begin{array}{l}\text { 10-Mevzuata } \\
\text { Uyma }\end{array}$} & Müdür & 51 & 3.30 & .80 & G. Arası & 4.06 & 2 & 2.03 & 2.78 & .06 \\
\hline & M. Yard. & 103 & 3.20 & .83 & G. İçi & 371.37 & 508 & .73 & & \\
\hline & Öğretmen & 357 & 3.05 & .86 & Toplam & 375.44 & 510 & & & \\
\hline & Toplam & 511 & 3.10 & .85 & & & & & & \\
\hline \multirow{4}{*}{$\begin{array}{l}\text { 11-Mesleki } \\
\text { Yeterlilikler }\end{array}$} & Müdür & 51 & 4.09 & .68 & G. Aras1 & 5.06 & 2 & 2.53 & 4.08 & .01 \\
\hline & M. Yard. & 103 & 3.79 & .79 & G. İçi & 315.06 & 508 & .62 & & \\
\hline & Öğretmen & 357 & 3.75 & .79 & Toplam & 320.13 & 510 & & & \\
\hline & Toplam & 511 & 3.79 & .79 & & & & & & \\
\hline
\end{tabular}

Tablo 5'te verilen Hesap Verebilirlik Politikaları ölçek puanlarının branş değişkenine göre anlamlı bir farklılık gösterip göstermediğini belirlemek amacıyla gerçekleştirilen tek yönlü varyans analizi sonuçlarına göre, hesap verebilirlik politikalarına ilişkin görüşlerde mesleki gelişim, ceza ve yaptırımlar, sorumluluk ve ödül, katılım, öğretmen otonomisi, bilgi, akademik standartlar, performans değerlendirmeleri, mevzuata uyma alt ölçeklerinde branşlarına göre anlamlı bir farklılık saptanmazken [p>.05]; öğrenci kazanım değerlendirmeleri $[F=3.28 ; p<.05]$ ve mesleki yeterlilikler alt ölçeklerinde anlamlı bir farklılık saptanmıştır [ $F=3.28 ; p<.05]$. ANOVA sonrası Levene's testi ile varyansların homojen olduğu saptanmıştır [p>.05]. Scheffe çoklu karşılaştırma analizi sonucunda ise, öğrenci kazanım değerlendirmeleri ve mesleki yeterlilikler puanlarının her birinin branş değişkeni sosyal bilimler öğretmeni grubuyla sınıf öğretmeni grubu arasında sosyal bilimler öğretmeni grubu lehine istatistiksel olarak [p<.05] düzeyinde anlamlı bir farklılık saptanmıştır. 
Tablo 5: Hesap Verebilirlik Politikaları Alt Ölçek Puanlarının Branş Değiş̧enine Göre Tek Yönlï Varyans Analizi (ANOVA) Sonuçları

\begin{tabular}{|c|c|c|c|c|c|c|c|c|c|c|}
\hline \multirow[b]{2}{*}{ Alt Ölçek } & \multirow[b]{2}{*}{ Branş } & \multicolumn{4}{|c|}{$N, X$ ve SS Değerleri } & \multicolumn{3}{|c|}{ ANOVA Sonuçları } & \multirow[b]{2}{*}{$\mathbf{F}$} & \multirow[b]{2}{*}{$\mathbf{P}$} \\
\hline & & $N$ & $X$ & SS & Var.K. & K.T. & SD & K.O. & & \\
\hline \multirow{8}{*}{$\begin{array}{l}\text { 1- } \\
\text { Mesleki } \\
\text { Gelişim }\end{array}$} & Sinif & 161 & 4.11 & .57 & G. Arası & 1.77 & 6 & .29 & 1.07 & .37 \\
\hline & Türkçe & 57 & 4.06 & .52 & G. İçi & 138.85 & 504 & .27 & & \\
\hline & Sosyal Bil. & 47 & 4.24 & .50 & Toplam & 140.62 & 510 & & & \\
\hline & Matematik & 45 & 4.12 & .50 & & & & & & \\
\hline & Fen Bil. & 44 & 4.16 & .53 & & & & & & \\
\hline & Meslek D. & 44 & 4.26 & .42 & & & & & & \\
\hline & Diğer & 113 & 4.17 & .50 & & & & & & \\
\hline & Toplam & 511 & 4.15 & .52 & & & & & & \\
\hline \multirow{8}{*}{$\begin{array}{l}2- \\
\text { Ceza } \\
\text { ve } \\
\text { Yaptirımlar }\end{array}$} & Sinif & 161 & 2.39 & .78 & G. Arası & 4.35 & 6 & .72 & 1.07 & .37 \\
\hline & Türkçe & 57 & 2.37 & .78 & G. İçi & 341.84 & 504 & .67 & & \\
\hline & Sosyal Bil. & 47 & 2.67 & .87 & Toplam & 346.20 & 510 & & & \\
\hline & Matematik & 45 & 2.27 & .86 & & & & & & \\
\hline & Fen Bil. & 44 & 2.46 & .92 & & & & & & \\
\hline & Meslek D. & 44 & 2.43 & .76 & & & & & & \\
\hline & Diğer & 113 & 2.42 & .84 & & & & & & \\
\hline & Toplam & 511 & 2.42 & .82 & & & & & & \\
\hline \multirow{8}{*}{$\begin{array}{l}\text { 3-Sorumlu- } \\
\text { luk ve Ödül }\end{array}$} & Sinıf & 161 & 3.70 & .72 & G. Arası & 3.01 & 6 & .50 & 1.20 & .30 \\
\hline & Türkçe & 57 & 3.79 & .65 & G. İçi & 210.83 & 504 & .41 & & \\
\hline & Sosyal Bil. & 47 & 3.89 & .59 & Toplam & 213.85 & 510 & & & \\
\hline & Matematik & 45 & 3.84 & .58 & & & & & & \\
\hline & Fen Bil. & 44 & 3.88 & .60 & & & & & & \\
\hline & Meslek D. & 44 & 3.92 & .58 & & & & & & \\
\hline & Diğer & 113 & 3.84 & .60 & & & & & & \\
\hline & Toplam & 511 & 3.81 & .64 & & & & & & \\
\hline \multirow{8}{*}{ 4-Katılım } & Sinıf & 161 & 2.96 & .63 & G. Arası & 2.33 & 6 & .38 & .83 & .54 \\
\hline & Türkçe & 57 & 2.99 & .72 & G. İçi & 234.28 & 504 & .46 & & \\
\hline & Sosyal Bil. & 47 & 3.02 & .78 & Toplam & 236.62 & 510 & & & \\
\hline & Matematik & 45 & 2.80 & .70 & & & & & & \\
\hline & Fen Bil. & 44 & 2.99 & .69 & & & & & & \\
\hline & Meslek D. & 44 & 3.11 & .70 & & & & & & \\
\hline & Diğer & 113 & 2.96 & .65 & & & & & & \\
\hline & Toplam & 511 & 2.97 & .68 & & & & & & \\
\hline \multirow{8}{*}{$\begin{array}{l}\text { 5-Öğretmen } \\
\text { Otonomisi }\end{array}$} & Sinif & 161 & 3.74 & .77 & G. Arası & 2.37 & 6 & .39 & .65 & .68 \\
\hline & Türkçe & 57 & 3.70 & .71 & G. İçi & 303.87 & 504 & .60 & & \\
\hline & Sosyal Bil. & 47 & 3.77 & .92 & Toplam & 306.24 & 510 & & & \\
\hline & Matematik & 45 & 3.76 & .74 & & & & & & \\
\hline & Fen Bil. & 44 & 3.98 & .77 & & & & & & \\
\hline & Meslek D. & 44 & 3.76 & .72 & & & & & & \\
\hline & Diğer & 113 & 3.77 & .77 & & & & & & \\
\hline & Toplam & 511 & 3.77 & .77 & & & & & & \\
\hline $6-$ & Sinif & 161 & 3.98 & .73 & G. Arası & 5.16 & 6 & .86 & 1.77 & .10 \\
\hline Bilgi & Türkçe & 57 & 3.85 & .70 & G. İçi & 244.86 & 504 & .48 & & \\
\hline
\end{tabular}




\begin{tabular}{|c|c|c|c|c|c|c|c|c|c|c|}
\hline & Sosyal Bil. & 47 & 4.21 & .55 & Toplam & 250.03 & 510 & & & \\
\hline & Matematik & 45 & 4.00 & .69 & & & & & & \\
\hline & Fen Bil. & 44 & 3.89 & .78 & & & & & & \\
\hline & Meslek D. & 44 & 4.15 & .57 & & & & & & \\
\hline & Diğer & 113 & 3.96 & .70 & & & & & & \\
\hline & Toplam & 511 & 3.99 & .70 & & & & & & \\
\hline \multirow{8}{*}{$\begin{array}{l}\text { 7-Akademik } \\
\text { Standartlar }\end{array}$} & Sinif & 161 & 3.08 & .82 & G. Arası & 1.76 & 6 & .29 & .44 & .84 \\
\hline & Türkçe & 57 & 3.14 & .81 & G. İçi & 332.01 & 504 & .65 & & \\
\hline & Sosyal Bil. & 47 & 3.08 & .80 & Toplam & 333.78 & 510 & & & \\
\hline & Matematik & 45 & 3.17 & .76 & & & & & & \\
\hline & Fen Bil. & 44 & 3.26 & .96 & & & & & & \\
\hline & Meslek D. & 44 & 3.14 & .75 & & & & & & \\
\hline & Diğer & 113 & 3.05 & .76 & & & & & & \\
\hline & Toplam & 511 & 3.11 & .80 & & & & & & \\
\hline \multirow{8}{*}{$\begin{array}{l} \\
\text { 8- } \\
\text { Öğrenci Ka- } \\
\text { zanım Değer- } \\
\text { lendirmeleri }\end{array}$} & Sinif & 161 & 3.63 & .82 & G. Aras1 & 12.02 & 6 & 2.00 & 3.28 & .00 \\
\hline & Türkçe & 57 & 3.83 & .61 & G. İçi & 308.10 & 504 & .61 & & \\
\hline & Sosyal Bil. & 47 & 4.14 & .67 & Toplam & 320.13 & 510 & & & \\
\hline & Matematik & 45 & 3.79 & .75 & & & & & & \\
\hline & - Fen Bil. & 44 & 3.77 & .84 & & & & & & \\
\hline & Meslek D. & 44 & 3.99 & .77 & & & & & & \\
\hline & Diğger & 113 & 3.80 & .82 & & & & & & \\
\hline & Toplam & 511 & 3.79 & .79 & & & & & & \\
\hline \multirow{8}{*}{$\begin{array}{l} \\
\text { 9-Performans } \\
\text { Değerlendir- } \\
\text { meleri }\end{array}$} & Sinif & 161 & 3.28 & .68 & G. Arası & .26 & 6 & .04 & .097 & .99 \\
\hline & Türkçe & 57 & 3.33 & .58 & G. İçi & 227.99 & 504 & .45 & & \\
\hline & sSosyal Bil. & 47 & 3.35 & .76 & Toplam & 228.25 & 510 & & & \\
\hline & Matematik & 45 & 3.32 & .63 & & & & & & \\
\hline & Fen Bil. & 44 & 3.30 & .64 & & & & & & \\
\hline & Meslek D. & 44 & 3.28 & .64 & & & & & & \\
\hline & Diğger & 113 & 3.32 & .69 & & & & & & \\
\hline & Toplam & 511 & 3.31 & .66 & & & & & & \\
\hline \multirow{8}{*}{$\begin{array}{l} \\
\text { 10-Mevzuata } \\
\text { Uyma }\end{array}$} & Sinif & 161 & 3.13 & .94 & G. Arası & 8.06 & 6 & 1.34 & 1.84 & .08 \\
\hline & Türkçe & 57 & 3.05 & .77 & G. İçi & 367.37 & 504 & .72 & & \\
\hline & Sosyal Bil. & 47 & 3.12 & .88 & Toplam & 375.44 & 510 & & & \\
\hline & Matematik & 45 & 3.33 & .81 & & & & & & \\
\hline & Fen Bil. & 44 & 3.32 & .79 & & & & & & \\
\hline & Meslek D. & 44 & 3.06 & .78 & & & & & & \\
\hline & Diğer & 113 & 2.93 & .80 & & & & & & \\
\hline & Toplam & 511 & 3.10 & .85 & & & & & & \\
\hline \multirow{8}{*}{$\begin{array}{l}11- \\
\text { Mesleki } \\
\text { Yeterlilik } \\
\text { ler }\end{array}$} & Sinif & 161 & 3.63 & .82 & G. Arası & 12.02 & 6 & 2.00 & 3.28 & .00 \\
\hline & Türkçe & 57 & 3.83 & .61 & G. İçi & 308.10 & 504 & .61 & & \\
\hline & Sosyal Bil. & 47 & 4.14 & .67 & Toplam & 320.13 & 510 & & & \\
\hline & Matematik & 45 & 3.79 & .75 & & & & & & \\
\hline & Fen Bil. & 44 & 3.77 & .84 & & & & & & \\
\hline & Meslek D. & 44 & 3.99 & .77 & & & & & & \\
\hline & Diğer & 113 & 3.80 & .82 & & & & & & \\
\hline & Toplam & 511 & 3.79 & .79 & & & & & & \\
\hline
\end{tabular}


Tablo 6'da verilen Hesap Verebilirlik Politikaları ölçek puanlarının üye olunan sendika değişkenine göre anlamlı bir farklılık gösterip göstermediğini belirlemek amacıyla gerçekleştirilen tek yönlü varyans analizi sonuçlarına göre, okul yöneticileri ve öğretmenlerin hesap verebilirlik politikalarına ilişkin görüşleri mesleki gelişim, ceza ve yaptırımlar, sorumluluk ve ödül, öğretmen otonomisi, bilgi, akademik standartlar, öğrenci kazanım değerlendirmeleri, performans değerlendirmeleri, mevzuata uyma, mesleki yeterlilikler alt ölçeklerinde üye olunan sendikaya göre anlamlı bir farklılık saptanmazken [p>.05]; katılım [F=2.78; $p<.05]$ alt ölçeğinde anlamlı bir farklılık saptanmıştır. ANOVA sonrası Levene's testi ile grup dağılımlarının varyanslarının homojen olduğu saptanmıştır [p>.05]. Scheffe çoklu karşılaştırma analizi sonucu katılım puanlarının üye olunan sendika değişkenine göre Türk-Eğitim-Sen grubuyla, Eğitim-Sen, EğitimBir-Sen ve diğer sendika grupları arasında Türk-Eğitim-Sen grubu aleyhine istatistiksel olarak $[\mathrm{p}<.05]$ düzeyinde anlamlı bir farklılık saptanmıştır.

Tablo 6: Hesap Verebilirlik Politikalan Alt Ölçek Puanlarının Üye OlunanSendika Değişkenine Göre Tek Yönlii Varyans Analizi (ANOVA) Sonuçlan

\begin{tabular}{|c|c|c|c|c|c|c|c|c|c|c|}
\hline \multirow[b]{2}{*}{ Alt Ölçek } & \multicolumn{5}{|c|}{$N$, X ve SS Değerleri } & \multicolumn{5}{|c|}{ ANOVA Sonuçları } \\
\hline & $\begin{array}{l}\text { Üye Olunan } \\
\text { Sendika }\end{array}$ & $\mathbf{N}$ & $X$ & $S S$ & Var. K. & K.T. & SD & K.O. & $\mathbf{F}$ & $\mathbf{P}$ \\
\hline \multirow{7}{*}{$\begin{array}{l}\text { 1- } \\
\text { Mesleki } \\
\text { Gelişim }\end{array}$} & Eğit.S. & 13 & 4.38 & .49 & G. Arasi & 2.21 & 5 & .44 & 1.59 & .16 \\
\hline & Ĕgit.B.S & 147 & 4.15 & .52 & G. İçi & 134.44 & 484 & .27 & & \\
\hline & Türk Eğ.S. & 138 & 4.09 & .53 & Toplam & 136.65 & 489 & & & \\
\hline & Eğitim İş & 18 & 4.38 & .35 & & & & & & \\
\hline & Diğer & 29 & 4.20 & .58 & & & & & & \\
\hline & Üye Değil & 145 & 4.14 & .52 & & & & & & \\
\hline & Toplam & 490 & 4.15 & .52 & & & & & & \\
\hline \multirow{7}{*}{$\begin{array}{l}2- \\
\text { Ceza ve } \\
\text { Yaptirımlar }\end{array}$} & Eğit.S. & 13 & 1.96 & .73 & G. Arası & 3.73 & 5 & .74 & 1.10 & .35 \\
\hline & Eğit.B.S & 147 & 2.47 & .85 & G. İçi & 327.82 & 484 & .67 & & \\
\hline & Türk Eğ.S. & 138 & 2.36 & .78 & Toplam & 331.55 & 489 & & & \\
\hline & Eğitim İş & 18 & 2.44 & .76 & & & & & & \\
\hline & Diğer & 29 & 2.47 & .77 & & & & & & \\
\hline & Üye Değil & 145 & 2.37 & .84 & & & & & & \\
\hline & Toplam & 490 & 2.40 & .82 & & & & & & \\
\hline 3-Sorumlu- & Eğit.S. & 13 & 3.92 & .67 & G. Aras1 & 1.82 & 5 & .36 & .85 & .50 \\
\hline luk ve Ödül & Eğit.B.S & 147 & 3.74 & .68 & G. İçi & 205.80 & 484 & .42 & & \\
\hline
\end{tabular}




\begin{tabular}{|c|c|c|c|c|c|c|c|c|c|c|}
\hline & Türk Ĕ̆g.S. & 138 & 3.80 & .66 & Toplam & 207.63 & 489 & & & \\
\hline & Eğitim İş & 18 & 4.05 & .51 & & & & & & \\
\hline & Diğer & 29 & 3.81 & .65 & & & & & & \\
\hline & Üye Değil & 145 & 3.82 & .61 & & & & & & \\
\hline & Toplam & 490 & 3.80 & .65 & & & & & & \\
\hline \multirow{7}{*}{$\begin{array}{l}4- \\
\text { Katılım }\end{array}$} & Eğit.S. & 13 & 3.30 & .74 & G. Arası & 6.25 & 5 & 1.25 & 2.78 & .01 \\
\hline & Eğit.B.S & 147 & 3.01 & .67 & G. İçi & 217.47 & 484 & .44 & & \\
\hline & Türk Ĕ̆g.S. & 138 & 2.84 & .66 & Toplam & 223.72 & 489 & & & \\
\hline & Eğitim İş & 18 & 3.13 & .60 & & & & & & \\
\hline & Diğer & 29 & 3.20 & .65 & & & & & & \\
\hline & Üye Değil & 145 & 2.91 & .66 & & & & & & \\
\hline & Toplam & 490 & 2.96 & .67 & & & & & & \\
\hline \multirow{7}{*}{$\begin{array}{l}\text { 5-Öğretmen } \\
\text { Otonomisi }\end{array}$} & Eğit.S. & 13 & 4.23 & .72 & G. Arası & 6.01 & 5 & 1.20 & 2.03 & .07 \\
\hline & Eğit.B.S & 147 & 3.81 & .77 & G. İçi & 285.83 & 484 & .59 & & \\
\hline & Türk Ĕ̆g.S. & 138 & 3.67 & .80 & Toplam & 291.85 & 489 & & & \\
\hline & Eğitim İş & 18 & 3.75 & .79 & & & & & & \\
\hline & Diğer & 29 & 4.01 & .69 & & & & & & \\
\hline & Üye Değil & 145 & 3.75 & .74 & & & & & & \\
\hline & Toplam & 490 & 3.77 & .77 & & & & & & \\
\hline \multirow{7}{*}{$\begin{array}{l}\text { 6- } \\
\text { Bilgi }\end{array}$} & Eğit.S. & 13 & 4.18 & .82 & G. Aras1 & 1.42 & 5 & .28 & .58 & .71 \\
\hline & Ĕ̆it.B.S & 147 & 3.99 & .64 & G. İçi & 237.08 & 484 & .49 & & \\
\hline & Türk Ĕ̆.S. & 138 & 3.93 & .69 & Toplam & 238.51 & 489 & & & \\
\hline & Eğitim İş & 18 & 4.13 & .68 & & & & & & \\
\hline & Diğer & 29 & 4.03 & .76 & & & & & & \\
\hline & Üye Değil & 145 & 4.00 & .73 & & & & & & \\
\hline & Toplam & 490 & 3.99 & .69 & & & & & & \\
\hline \multirow{7}{*}{$\begin{array}{l}\text { 7-Akademik } \\
\text { Standartlar }\end{array}$} & Eğit.S. & 13 & 2.93 & 1.01 & G. Arası & 1.18 & 5 & .23 & .36 & .87 \\
\hline & Eğit.B.S & 147 & 3.09 & .80 & G. İçi & 319.59 & 484 & .66 & & \\
\hline & Türk Eğ.S. & 138 & 3.15 & .82 & Toplam & 320.78 & 489 & & & \\
\hline & Eğitim İ & 18 & 3.22 & .82 & & & & & & \\
\hline & Diğer & 29 & 3.05 & .95 & & & & & & \\
\hline & Üye Değil & 145 & 3.07 & .76 & & & & & & \\
\hline & Toplam & 490 & 3.10 & .80 & & & & & & \\
\hline \multirow{7}{*}{$\begin{array}{l}\text { 8- } \\
\text { Ö̈̆renci Ka- } \\
\text { zanım Değer- } \\
\text { lendirmeleri }\end{array}$} & Eğit.S. & 13 & 3.73 & .83 & G. Arası & 4.45 & 5 & .89 & 1.42 & .21 \\
\hline & Eğit.B.S & 147 & 3.86 & .83 & G. İçi & 302.64 & 484 & .62 & & \\
\hline & Türk Eğ.S. & 138 & 3.67 & .77 & Toplam & 307.09 & 489 & & & \\
\hline & Eğitim İş & 18 & 4.08 & .69 & & & & & & \\
\hline & Diğer & 29 & 3.70 & .87 & & & & & & \\
\hline & Üye Değil & 145 & 3.80 & .74 & & & & & & \\
\hline & Toplam & 490 & 3.78 & .79 & & & & & & \\
\hline \multirow{7}{*}{$\begin{array}{l} \\
\text { 9-Performans } \\
\text { Değerlendir- } \\
\text { meleri }\end{array}$} & Eğit.S. & 13 & 3.25 & .59 & G. Arası & 3.18 & 5 & .63 & 1.42 & .21 \\
\hline & Eğit.B.S & 147 & 3.23 & .69 & G. İçi & 216.27 & 484 & .44 & & \\
\hline & Sürk Eğ.S. & 138 & 3.31 & .69 & Toplam & 219.46 & 489 & & & \\
\hline & Eğitim İş & 18 & 3.65 & .56 & & & & & & \\
\hline & Diğer & 29 & 3.39 & .63 & & & & & & \\
\hline & Üye Değil & 145 & 3.27 & .63 & & & & & & \\
\hline & Toplam & 490 & 3.29 & .66 & & & & & & \\
\hline
\end{tabular}




\begin{tabular}{llccclrrrrr}
\hline \hline & Eğit.S. & 13 & 3.26 & 1.09 & G. Arası & 3.79 & 5 & .75 & 1.01 & .40 \\
& Eğit.B.S & 147 & 3.16 & .87 & G. İçi & 360.25 & 484 & .74 & & \\
10-Mevzuata & Türk Eğ.S. & 138 & 3.07 & .87 & Toplam & 364.04 & 489 & & & \\
Uyma & Eğitim İş & 18 & 3.25 & .66 & & & & & & \\
& Diğer & 29 & 2.84 & 1.07 & & & & & & \\
& Üye Değil & 145 & 3.04 & .78 & & & & & & \\
& Toplam & 490 & 3.09 & .86 & & & & & & \\
\hline \multirow{5}{*}{$11-$} & Eğit.S. & 13 & 3.73 & .83 & G. Arası & 4.45 & 5 & .89 & 1.42 & .21 \\
Mesleki & Eğit.B.S & 147 & 3.86 & .83 & G. İçi & 302.64 & 484 & .62 & & \\
Yeterlilikler & Türk Eğ.S. & 138 & 3.67 & .77 & Toplam & 307.09 & 489 & & & \\
& Eğitim İş̧ & 18 & 4.08 & .69 & & & & & & \\
& Diğer & 29 & 3.70 & .87 & & & & & & \\
& Üye Değil & 145 & 3.80 & .74 & & & & & & \\
& Toplam & 490 & 3.78 & .79 & & & & & & \\
\hline
\end{tabular}

Tablo 7'de verilen Hesap Verebilirlik Politikaları Ölçek puanlarının okul tipine göre anlamlı bir farklılık gösterip göstermediğini belirlemek amacıyla gerçekleştirilen bağımsız gruplar t-testi sonuçlarına göre, okul yöneticileri ve öğretmenlerin hesap verebilirlik politikaları ve uygulamalarına ilişkin görüşleri mesleki gelişim, sorumluluk ve ödül, katıllm, öğretmen otonomisi, bilgi, mevzuata uyma alt ölçeklerinde okul yöneticileri ve öğretmenlerin görev yaptıkları okul türü değişkenine göre anlamlı bir farklılık saptanmazken [p>.05]; ceza ve yaptırmlar, akademik standartlar, öğrenci kazanım değerlendirmeleri, performans değerlendirmeleri, mesleki yeterlilikleri alt ölçeklerinde özel okullar lehine anlamlı bir farklılık saptanmıştır [ $p<.05]$.

Tablo 7: Hesap Verebilirlik Politikaları Alt Ölçek Puanlarının Okul Tipi Değişkenine Göre t-Testi Sonuçlarn

\begin{tabular}{|c|c|c|c|c|c|c|}
\hline Alt Ölçekler & Okul Tipi & $N$ & $X$ & SS & $t$ & $P$ \\
\hline \multirow{2}{*}{ 1-Mesleki Gelişim } & Kamu & 462 & 4.14 & .52 & \multirow{2}{*}{-1.26} & \multirow{2}{*}{.20} \\
\hline & Özel & 49 & 4.24 & .50 & & \\
\hline \multirow{2}{*}{ 2-Ceza ve Yaptırımlar } & Kamu & 462 & 2.37 & .81 & \multirow{2}{*}{-4.33} & \multirow{2}{*}{.00} \\
\hline & Özel & 49 & 2.90 & .79 & & \\
\hline \multirow{2}{*}{ 3-Sorumluluk ve Ödül } & Kamu & 462 & 3.80 & .65 & \multirow{2}{*}{-.99} & \multirow{2}{*}{.32} \\
\hline & Özel & 49 & 3.89 & .57 & & \\
\hline \multirow{2}{*}{ 4-Katılım } & Kamu & 462 & 2.96 & .67 & \multirow{2}{*}{-1.30} & \multirow{2}{*}{.19} \\
\hline & Özel & 49 & 3.09 & .76 & & \\
\hline
\end{tabular}




\begin{tabular}{lllllll}
\hline \multirow{2}{*}{ 5-Öğretmen Otonomisi } & Kamu & 462 & 3.77 & .76 & .18 & .85 \\
& Özel & 49 & 3.75 & .90 & & \\
6-Bilgi & Kamu & 462 & 3.99 & .68 & & \\
& Özel & 49 & 4.03 & .83 & -.36 & .71 \\
7-Akademik Standartlar & Kamu & 462 & 3.08 & .80 & & \\
& Özel & 49 & 3.37 & .76 & -2.39 & .01 \\
8-Öğrenci Kazanım Değer- Kamu & 462 & 3.77 & .77 & & \\
lendirmeleri & Özel & 49 & 4.02 & .88 & -2.09 & .03 \\
9-Performans Değer- & Kamu & 462 & 3.28 & .67 & & \\
lendirmeleri & Özel & 49 & 3.58 & .50 & -3.02 & .00 \\
\multirow{2}{*}{ 10-Mevzuata Uyma } & Kamu & 462 & 3.08 & .85 & & \\
& Özel & 49 & 3.29 & .82 & -1.61 & .10 \\
11-Mesleki Yeterlilikler & Kamu & 462 & 3.77 & .77 & & \\
& Özel & 49 & 4.02 & .88 & -2.09 & .03 \\
\hline
\end{tabular}

$S D=509$

\section{Tartışma veYorum}

Bulgulara göre, öğrencilerin akademik başarılarını artırmak amacıyla okul temelli olarak geliştirilen hesap verebilirlik politikalarına öğretmen ve okul yöneticilerinin farklı düzeylerde destek verdiği, verilen desteğin ise kurum ve öğretmen özelliklerine bağlı alt gruplar arasında farklılaştığ tespit edilmiştir. İlk olarak, okul yöneticileri ve öğretmenlerin daha çok profesyonel hesap verebilirlik politikalarını öğrenci başarısının artırılmasında bir çözüm yaklaşımı olarak gördükleri anlaşılmaktadır. Bürokratik, piyasa ve performans hesap verebilirliği politikalarına karşı öğretmen ve okul yöneticilerinin desteği ise daha düşük düzeyde kalmıştır. İkinci olarak, akademik başarıya ilişkin standartların belirlenmesi, performans değerlendirmelerinin yapılması, velilerin öğretim süreçlerine ve kararlarına katılımlarının sağlanması ile mevzuata uygunluk mekanizmalarının gerekliliğine kısmen desteklenirken, başarısız öğretmenlere ve okullara ceza ve yaptırım uygulamasına destek verilmemektedir. Üçüncü olarak, hesap verebilirlik mekanizmalarına verilen destek cinsiyet, görev, 
üye olunan sendika gibi bireysel özelliklerine bağlı olarak oluşan alt gruplar arasında farklılaşmaktadır. Öğretmenler ve okul yöneticileri mesleki yeterlikler mekanizmasının gerekliliğini yüksek düzeyde desteklemektedir. Erkekler kadınlara, okul müdürleri öğretmenlere ve özel okullarda görev yapanlar kamuda görev yapanlara kıyasla bu politikaya daha çok destek göstermektedirler. Literatürde de, nitelikli ve başarılı bir öğretim için öğretmenlerin mesleki bilgi, beceriler ve tutumlarına ilişkin yeterliklerin çok önemli olduğu, öğretmenler ve adaylarının da genel olarak öğrencilerin akademik başarılarının artırılması konusunda öğretmenlerin yüksek mesleki yeterliklere sahip olmaları gerektiği, öğretmenlerin bilgi ve beceri düzeylerinin artırılmasının gerekliliğine inandıkları gösterilmiştir (Ekici, 2014; Koçak, Turan \& Aydoğdu, 2012; Mete \& Gürsoy, 2014). Bunun bir yansıması olarak, öğretmenlere ve öğretmen adaylarına bu yeterlikleri ne derece sahip oldukları sorulduğunda da çoğunlukla mesleki olarak kendilerini yeterli gördüklerini bildirmektedir (bkz. Aktağ \& Mirzeoğlu; 2007; Taşar, 2012). Genel olarak yapılan çalışmalar, öğretmenler ve öğretmen adaylarının alan bilgisi (Baybınar, Tarım \& Keklik, 2015; Özgen, 2016), alan öğretimi (Çimen \& Yılmaz, 2014; Dinçer, Akarsu \& Yılmaz, 2016), bilgisayar ve teknoloji kullanımı (Sezer, Yıldırım \& Pınar, 2012; Hark Söylemez \& Oral, 2014 ), ölçme ve değerlendirme bilgi ve becerileri (Gencel \& Özbaşı, 2014; Yaman \& Karamustafaoğlu, 2011; Yavuz, 2011; Yeşil, 2009; Şahin \& Uysal, 2014) konularında öğretmenlerin kendilerinin ortalamanın üstünde bir yeterlik düzeyine sahip olduğunu belirtmektedir. Coğrafya öğretmenlerinin yeterliklerinin gözleme dayalı ölçümünde ise hem alan hem de öğretiminde yeterli düzeyde olmadıkları tespit edilmiştir (Öztürk \& Eroğlu, 2013).

Öğrenci başarısının artırılmasında öğretmenlere gerekli özerkliğin sağlanması gerektiği düşüncesi okul yöneticileri ve öğretmenler tarafından yüksek düzeyde desteklenmektedir. Bu destek öğretmen ve okul özelliklerine göre oluşan alt gruplar arasında farklılaşmamaktadır. Literatürde de öğretmen özerkliğine verilen destek ampirik olarak da 
gösterilmiştir. Öğretmenler mesleklerinin icrası konusunda özerklik talep etmekte (Üzüm \& Karslı, 2014), üst yönetimce belirlenen kazanımlara ulaşma konusunda yapılacakların belirlenmesinin kendilerine bırakılmasını istemekte, yönetim kararlarında söz sahibi olma, hatta kendi yöneticilerini seçebilme, öğrencilere disiplinsizlik ve başarısızlık durumlarında yaptırım uygulayabilme konularında yetki talebinde bulunmaktadır (Özaslan, 2015). Friedman (1999) Birleşik Devletler öğretmenlerinin sınıf içi öğretim, okulun işleyişi, çalışanların gelişimi ve müfredatın geliştirilmesi hususlarında özerklik talep ettiklerini bildirmektedir. Özellikle öğretmenlerin program özerkliği talepleri öğretmenlerin okul kademesi ve branşlarına göre farklılaşmaktadır (Koçak, Turan \& Aydoğdu, 2012).

Öğrenci başarısının artırılmasında öğretmenlerin sorumlu tutulması gerektiği düşüncesi okul yöneticileri ve öğretmenler tarafından yüksek düzeyde desteklenmektedir. Verilen destek ise okul ve öğretmen özelliklerine göre oluşan alt gruplar arasında farklılaşmamaktadır. Bu destek literatürde de ampirik olarak gösterilmiştir. Öğretmen adayları öğrencilerin akademik başarı veya başarısızlığında ilk sorumluluğun öğretmene ait olduğu görüşünü paylaştıklarını belirtmektedir (Ekici, 2014). Bu açıdan bakıldığında öğretmenler, öğrenci başarısını artırmak için gerekli olan öğretim etkinliklerinin belirlenmesi ve kararların alınmasında hem özerklik talep etmekte, hem de sorumluluğu üstlenmeye hazır olduklarını beyan etmektedir. Diğer taraftan, Türkiye'deki bir çalışmada öğretmenlerin sorumluluklarını pozisyonları ile sınırlandırma eğiliminde oldukları, başarısızlık durumunda sorunu başkalarında aradıkları ve sorumluluk üstlenme konusunda isteksiz davrandıkları, karşılaştıkları sorunların çözümünü yöneticilerden bekledikleri sonucuna ulaşılmıştır (Turhan, Karabatak \& Polat, 2014). Buradan hareketle, öğretmenlerin başarıdan sorumlu olmaları bir retorik olarak desteklendiğini, fakat, pratikte üstlenilmesinin çok arzu edilen bir durum olmadığ 1 şeklinde 
yorumlanabilir. Bu ikilemin, çalışma ortamında sahip olunan olumsuz değer ve inançların bir yansıması olduğu düşünülmektedir.

Öğrenci başarısının artırılmasında öğrenci başarısının izlenmesi ve performans bilgisinin üretilmesi ve yayılması mekanizmalarının gerekliliği düşüncesi okul yöneticileri ve öğretmenler tarafından yüksek düzeyde desteklenmektedir. Performans bilgisinin üretilmesi ve yayılması politikasına verilen destek öğretmen ve yönetici alt gruplarına göre farklılaşmazken, öğrenci başarısının izlenmesi politikasına erkekler kadınlara, okul müdürleri öğretmenlere ve özel okullarda görev yapanlar kamuda görev yapanlara kıyasla daha çok desteklemektedir. Benzer olarak, okulların ulusal ve bölge şartlarına göre başarı düzeylerinin sürekli olarak izlenmesi ve sonuçların okulun tüm paydaşlarına belli aralıklarla rapor edilmesini öğretmenler desteklediği literatürde de rapor edilmiştir (Sumak \& Roşan, 2015). Başka bir çalışmada, öğretmenler öğrenmenin ve öğretimin izlenmesi olgusunu kaliteli okulların bir özelliği olarak görmekte, bu durum cinsiyet, kıdem ve okul kademesine göre değişmemektedir (Türkyılmaz \& Kuş, 2010). Diğer taraftan, hesap verebilirlik sistemlerinde önemli bir araç olarak yer verilen standart sınavlar, öğretim programının yetiştirilmesi ve öğrencilerin merkezi sınavlara hazırlanması konusunda öğretmenler üzerinde kaygı yarattığı rapor edilmiştir (Certo, 2006; Valli \& Buese, 2007).

Öğretmen ve okul yöneticileri, öğrencilerin başarısının artırılmasını sağlayan öğretmen ve okulların ödüllendirilmesi politikasına destek vermektedir. Literatürde de öğretmenler ve yöneticiler başarılı öğretmenlerin ödüllendirilmesi politikasına destek vermektedir (Sabancı, 1999; Seyhani, Özder \& Konedralı, 2009). Öğretmenler başarılarının çalıştıkları kurumları tarafından takdir edilmesini ve ödüllendirilmeyi istemekte (Çelebi, Vuranak \& Turgut, 2015), ödüllendirmelerde ise öğrenci akademik başarısını belirleyen dış faktörlerin etkisinin izole edilmesi gerektiğini savunmaktadır (Bakioğlu \& Salduz, 2014). 
Öğretmenler ve okul yöneticileri mesleki gelişim mekanizmasının gerekliliğini yüksek düzeyde desteklemektedir. Mesleki gelişim mekanizmasına verilen bu destek literatürde ampirik olarak da gösterilmiştir. Türkiye'de öğretmenler mesleki gelişimi yeniliklere ayak uydurma, kendini güncel tutma, değişimlere ayak uydurma, kendini yenilemek, kendini geliştirme, alana ilişkin bilgi ve beceriyi artırma, akademik başarıyı artırma ve okulu geliştirme olarak algılamakta ve bir gereklilik olarak görmektedir (Altun \& Vural, 2012; Ceylan \& Özdemir, 2016; Gökmenoğlu ve diğerleri, 2015; Boydak-Özan ve diğerleri, 2014; Kayabaş, 2008; Türkyılmaz \& Kuş, 2010; Uştu, Mentiş \& Sever, 2016; Gültekin \& Çubukçu, 2008; Runhaar, 2008). Diğer taraftan, öğretmenlerin mesleki gelişimlerinin sağlanması politikasına verilen desteğin görev değişkenine göre farklılaşmadığı yönündeki hipotez kabul edilmemiştir. Buna göre, okul müdürleri öğretmenlere kıyasla mesleki gelişim mekanizmasının gerekliliğine daha çok destek sağlamaktadır. Literatürde bu bulguyu destekleyen bir çalışmaya rastlanmaz iken, mesleki gelişimin gerekliliği cinsiyet ve okul kademesine göre değiştiği gösterilmiştir (Türkyılmaz \& Kuş, 2010).

Yüksek öğrenci başarısı için uygun başarı standartlarına sahip olunmasının gerektiği düşüncesi öğretmenler ve okul yöneticilerince kısmen destek görmektedir. Verilen destek kamuda görev yapanlara kıyasla özel okulda görev yapan öğretmenler arasında daha çok desteklemektedir. Elde edilen bu bulgu öğretmenlerin başarılı okulları yüksek standartlarla nitelendirme eğiliminde oldukları bulgusuyla örtüşmemektedir. Standartlara verilen önem cinsiyete göre değişmezken, ilkokullardaki öğretmenler arasında ortaokullara kıyasla daha çok önemsediği bildirilmektedir (Türkyılmaz \& Kuş, 2010).

Öğretmen ve yöneticilerin performans değerlendirme politikasına yeterince destek vermediği tespit edilmiştir. Kadınlar erkeklere, öğretmenler okul müdürlerine ve kamu okullarında görev yapanlar özel 
okulda görev yapanlara kıyasla bu politikaya daha az destek vermektedirler. Öğretmenlerin ve okul yöneticilerinin performans değerlendirmelerinin gerekliliğine ilişkin kafa karışıklığı ve ayrışma literatürde de gösterilmektedir. Öğretmenler, performans değerlendirmelerinin okullara rekabet, iş yükü, baskı ve endişe getirdiğini bildirmekte, performans değerlendirmelerinin nerede, kim tarafından, nasıl yapılacağını bilinmediğinden sonucunun da adil olamayacağı endişeleri taşıdıkları, faydalarının daha az olacağından dolayı da desteklemedikleri rapor edilmiştir. Verilen desteğin ise cinsiyet, görev alt gruplarına göre farklılaştığı bildirilmektedir (Alay, 2006; Aygün, 2008; Ball, 2003; Ball \& Youdell, 2007; Buyruk, 2014; Mahony \& Hextall, 2000; Soydan, 2012; Soydan, Abalı \& Kalsen, 2014; Üstünkal, 2013).

Akademik başarının artırılması için okul yöneticileri ve öğretmenler veli katılımı politikasına yeterince destek vermemektedir. Okul yöneticileri öğretmenlere, erkekler kadınlara, fen/anadolu liselerinde görev yapanlar ortaokula, Türk Eğitim-Sen üyeleri Eğitim-Sen ve Eğitim-Bir-Sen üyelerine kıyasla veli katılımı politikasına daha çok destek vermektedir. Literatürde ise veli katılımının gerekliliğine ilişkin farklı düşüncelerin olduğu görülmektedir. Bir taraftan, öğretmenlerin ve velilerin yönetim süreçlerine katılımlarını okul müdürlerinin engellediği, öğretmenlerin ve velilerin ise isteksiz davrandığ1 (Şahin \& Çeper, 2013), diğer taraftan da velinin öğrencinin öğrenmesine olan desteğinin ilkokullarda düşük seviyede kaldığı, öğrencilerin ev öğrenmelerinde anne ve babalarının yeterince katkı sağlamadıkları (Saban \& Şeker, 2010; Aksu \& Karaçöp, 2015), öğretmen ve yöneticilerin ailelerin eğitim sürecine katılımının gereği konusunda hemfikir olduğu (Erdoğan \& Demirkasımoğlu, 2010) rapor edilmiştir. Velilerin okul süreçlerine katılımına ilişkin düşüncelerinde cinsiyet ve kıdem değişkenlerinin etki yaratmadığı, öte taraftan ortaokullara kıyasla ilkokullardaki öğretmenlerin veli katılımını daha çok önemsedikleri, anadolu liseleri ve ilkokullarda velilerin kararlara 
katılımlarının diğer okullara kıyasla daha fazla olduğu bildirilmiştir (Kartal, 2008; Türkyılmaz \& Kuş, 2010).

Öğretmenler ve okul yöneticileri öğrenci başarısının artırılması için başarısız öğretmen ve okullara ceza ve yaptırımların uygulanması politikasına destek vermemektedir. Bu politikaya, kadınlar erkeklere, öğretmenler okul müdürlerine ve kamuda görev yapanlar özel okullarda görev yapanlara, tecrübeli olmayanlar olanlara ve ön lisans mezunları lisans mezunlarına kıyasla başarısız okul ve personele ceza uygulanması politikasına daha az destek vermektedir. Ayrıca, ortaokullardaki öğretmenler fen lisesi/anadolu lisesinde görev yapan öğretmen ve yöneticilere kıyasla başarısız okulların cezalandırılması ve yaptırımlar uygulanması politikasına daha az destek vermektedirler. Bu bağlamda bazı öğretmen ve yönetici gruplarının başarısızlık halinde ceza uygulamasından daha çok endişe ve kaygı duydukları sonucu çıkarılabilir. Literatürde bu bulgular desteklenmektedir. Öğretmenler öğrencilerin başarısızlıkları nedeniyle kendilerinin cezalandırılmasının adil bir muamele olmadığı, buna karşın öğrencinin akademik başarısını belirleyen dış faktörlerin etkisinin arındırılması halinde daha adil bir uygulama olacağını düşünmektedir (Bakioğlu \& Salduz, 2014). Başka bir çalışmada ise, eğitimcilerin ceza uygulamalarını destekledikleri, bu desteğin öğretmenlere kıyasla okul yöneticileri tarafından daha çok desteklediği bildirilmektedir (Seyhani, Özder \& Konedralı, 2009).

Sonuç olarak, okullar veli, öğrenci, öğretmenler ve üst yönetim birimlerinin güçlendirilerek okullar üzerinde performans baskısı yapmaya yarayan bazı mekanizmaların hayata geçirilmesine destek verirken bazılarına ise destek vermemektedirler. Piyasa, performans ve profesyonel hesap verebilirlik mekanizmalarına daha yüksek destek verilmektedir. Önemli tecrübelere sahip olan yönetici ve öğretmenlerin politika yapıcılara verdiği temel mesaj şu şekilde okunabilir: Öğretim, öncelikle, yüksek niteliklere sahip öğretmenlerin bilgi ve becerisine emanet 
edilmelidir. İkinci olarak, yüksek yeterliklere sahip olan kaliteli bu öğretmenlerin değişen iç ve dış koşullara uyumlarının sağlanmalı, yeni bilgi ve becerilerin kazanmalarına olanak sağlayacak mekanizmalar veya yapılar geliştitilmelidir. Bu anlamda, okullar akademik başarının artırılmasının temel kaldıracı olarak yüksek öğretmen niteliklerine işaret etmektedir. Başka bir açıdan bakıldığında ise, bu mesaj günümüz öğretmen nitelikleri konusunda öğretmenlerin şüpheleri olduğunun bir göstergesi sayılabilir. Üçüncü olarak, öğrencilerin başarısında temel sorumluğu öğretmenin üstlenmesi, öğrencilerinin elde ettiği kazanımların sürekli izlenerek öğrenciye ne kazandırdığının diş etkilerden arındırılarak tespit edilmesi, performansının bu anlamda değerlendirilmesi, başarılı olanların ise ödüllendirilmesinin başarıyı artıracağını düşünmektedir. Dördüncü olarak, öğretmenler velilerin öğretim süreçlerine doğrudan veya dolaylı katılımlarına da kısmi olarak direnç göstermektedir. Öğrencilerin performansına ilişkin bilgi üretimi ve yayılımını desteklerken, velilerin okullar üzerinde başarı baskısı üretme, öğretim süreçlerinde ve kararlarında müdahil olmalarına sıcak bakmamaktadır.

Tüm bu çıkarımlar birlikte değerlendirildiğinde, Türkiye eğitim sisteminde yaşanılan akademik başarının düşüklügünün temel sebebinin bir kapasite ve motivasyon sorunu olduğu alandaki en tecrübeli kişiler olan öğretmenler ve yöneticiler tarafından bir kez daha teyit edilmektedir. Bir kapasite sorunudur, çünkü akademik başarının artırılması öğretmenlerin kapasitesinin artırılmasına bağlanmıştır. Bir motivasyon sorunudur, çünkü öğretmenler nitelikli öğretmenleri motive edecek sorumluluk duygusuna ve ödüllere olan ihtiyacı işaret etmektedir. $\mathrm{Bu}$ açıdan bakıldığında, akademik başarı probleminin çözümü öncelikle öğretmenlerin kapasitesinin artırılması, onunla beraber motivasyonlarının artırılmasına imkan sağlayacak hesap verebilirlik mekanizmalarının etkili bir kombinasyonu ile mümkün olacaktır. Bu anlamda, (i) nitelikli öğretmenlerin mesleğe girmesine imkan sağlayacak aday öğretmenlerin eğitim kurumlarına seçilmesi, eğitilmesi ve mesleğe girişleri yeniden 
yapılandırılmalı, (ii) üst yönetim ile okullar arasında öğrenci başarısının artırılmasına yönelik okulların öğretim sorumluluğu üstlendiği ve bu konuda yetkilendirildiği bir hesap verebilirlik mekanizması kurulmalıdır. Buradan hareketle, bundan sonraki araştırmalar okul kapasitesi ve öğretmen nitelikleri üzerinde etkisi olan yapısal faktörlerin tespiti ve sonrasında bütüncül bir yaklaşımla etkili bir öğretmen yetiştirme ve geliştirme modelinin oluşturulması üzerine odaklanmalıdır. Diğer taraftan, okul geliştirme araştırmaları okullarda başarının artırılmasına yönelik bir motivasyon mekanizmasının kurulması üzerine yoğunlaşmalıdır. Özellikle performans, piyasa ve profesyonel hesap verebilirlik mekanizmalarının öğrenci başarısı ve öğrenci başarısına temel olan öğrenme ortamları, okul iklimi, kültürü, öğretmen davranışları ve yönetici davranışları üzerindeki etkileri test edilmelidir.

\section{Kaynakça}

Adams, J. E. ve Kirst, M. (1999). New demands for educational accountability: Striving for results in an era of excellence. In J. Murphey ve K. S. Louis (Eds.), Handbook of research in educational administration (2nd ed., pp. 463-489). San Francisco: Jossey-Bass.

Akçakaya, M. ve Yücel, N. (2009). Küreselleşme sürecinde ulus devletin dönüşümü ve çok aktörlü yönetim tartışmaları. Retrieved from http://idc.sdu.edu.tr/tammetinler/ yonetim/ yonetim7.pdf

Aksu, F. ve Karaçöp, A. (2015). Ev Temelli Fen Öğrenme Etkinliklerine Aile Katılımının Bazı Değişkenler Açısından İncelenmesi. Bayburt Ĕ̆itim Fakültesi Dergisi, 10 (1), 154-179.

Aktağ, I. ve Mirzeoğlu, D . (2007). Öğretmenlerin Mesleki Yeterlik Duygularının Çeşitli Değişkenler Açısından İncelenmesi ( Bolu İli Örneği). Abant İzzet Baysal Üniversitesi Sosyal Bilimler Enstitüsü Dergisi, 15 (15), 34-44.

Alay, G. (2006). İlköğretim ve ortaöğretim kurumlarında görev yapan öğretmenlerin performans değerlendirme sistemine ilişkin 
görüşleri. YayımlanmamışYüksek Lisans Tezi, Gazi Üniversitesi Eğitim Bilimleri Enstitüsü, Ankara.

Altun, T. ve Vural, S. (2012). Bilim Ve Sanat Merkezinde (Bilsem) Görev Yapan Öğretmen Ve Yöneticilerin Mesleki Gelişim Ve Okul Gelişimine Yönelik Görüşlerinin Değerlendirilmesi. Elektronik Sosyal Bilimler Dergisi, 11 (42), 152-177

Aydın, A., Erdağ, C. ve Taş, N. (2011). 2003-2006 Pisa okuma becerileri sonuçlarının karşılaştırmalı olarak değerlendirilmesi: En başarılı beş ülke ve Türkiye. Kuram ve Uygulamada Ĕ̆itim Bilimleri Dergisi (KUYEB), 11 (2), 651-673.

Aydın, A., Sarıer, Y., Uysal, Ş. (2012). Sosyoekonomik ve sosyokültürel değişkenler açısından Pisa matematik sonuçlarının karşılaştırılması. Eğitim ve Bilim, 37 (164), 20-30.

Aygün, S. Ç. (2008). Ankara ili genel liselerinde performansa dayalı denetimin uygulanmasına ilişkin öğretmen görüşleri. Yayımlanmamış Yüksek Lisans Tezi, Ankara Üniversitesi Eğitim Bilimleri Enstitüsü, Ankara.

Bakioğlu, A. ve Salduz, E. (2014). Öğretmenlerin Hesap Verebilirliklerini Öğrencilerin Akademik Başarısı Açısından Değerlendirmeleri. Eğitim Bilimleri Dergisi, 40, Pp: 13-29.

Balcı, A. (2003). Kamu yönetiminde hesap verebilirlik anlayışı, A. Balcı, A. Nohutçu, N.K. Öztürk ve B. Coşkun (Editörler), Kamu yönetiminde çă̆daş yaklaşımlar. Ankara: Seçkin Yayıncılık.

Ball, S. J. ve Youdell, D. (2007). Hidden privatization in public education, preliminary report. Education International 5th World Congress.

Ball, S. J. (2003). Theteacher's soul and theterrors of performavity. Journal of Education Policy, 18(2), 215-228.

Baypınar, K.; Tarım, K. ve Keklik, G . (2015). İlköğretim Öğretmenlerinin Matematik Okuryazarlığı Öz-Yeterlik Düzeylerinin Çeşitli Değişkenler Açısından İncelenmesi. Adiyaman University Journal Of Social Sciences, 2015 (3), 846-870

Bilgiç, V. (2008). Yeni kamu yönetimi anlayışı, A. Balcı, A. Nohutçu, N.K. Öztürk,ve B. Coşkun (Editörler), Kamu yönetiminde çă̆daş yaklaşımlar, Ankara: Seçkin Yayıncilık.

Bovens, M. (2010). Two concepts of accountability: Accountability as a virtue and as a mechanism. West European Politics, 33 (5), 946-967. 
Boydak Ö. M.; Polat, H. ve Şener, G. (2014). Sınıf Öğretmenlerinin Mesleki Gelişim Eğitimlerine İlişkin Görüşlerinin Belirlenmesi. Uşak Üniversitesi Sosyal Bilimler Dergisi, 20(20), 167-180.

Bradshaw, M. D. (2003). A case study: Views of Bermudian stakeholders in education on the accountability of an outcome-based accountability system (Doctoral dissertation). Retrieved from ProQuest Dissertations and Theses. (UMI No. 3117857)

Bruns, B., Filmer, D. ve Patronas, H. A. (2011). Making schools work: New evidence on accountability reforms. The International Bank for Reconstruction and Development / The World Bank, Washington DC. Retrieved from http://siteresources.worldbank. org/EDUCATION/Resources/278200-1298568319076/ makingschoolswork.pdf

Buyruk, H. (2014). Öğretmen Performansının Göstergesi Olarak Merkezi Sınavlar Ve Eğitimde Performans Değerlendirme. Trakya Üniversitesi Ĕ̆itim Fakültesi Dergisi, 4 (2), Pp:

Certo, J. L. (2006). Beginning teacher concerns in an accountability-based testing environment. Journal of Research in Childhood Education, 20, 331-349.

Ceylan, M. ve Özdemir, S. (2016). Türkiye Ve İngiltere'deki Öğretmenlerin Sürekli Mesleki Gelişime İlişkin Görüşlerinin Ve Katılım Durumlarının İncelenmesi. Kırıkkale Üniversitesi Sosyal Bilimler Dergisi, 6 (1), 397-417.

Çelebi, N.; Vuranok, T. ve Turgut, I . (2015). İlk Ve Ortaokullarda Öğretmenlerin Ödül Sistemine İlişkin Görüşleri. Mehmet Akif Ersoy Üniversitesi Eğitim Fakültesi Dergisi, 1 (34), 75-104.

Çimen, O. ve Yılmaz, M . (2014). An Investıgatıon Of Bıology Preservice Teachers' Self-Efficacy Belıefs Regarding The Application Of Teachıng Methods And Technıques. Gazi Üniversitesi Gazi Eğitim Fakültesi Dergisi, 33 (1), 51-65.

Darling-Hammond, L. ve Ascher, C. (1991). Creating accountability in big city school systems-Urban diversity series no. 102. New York: ERIC Clearinghouse on Urban Education. (Eric Document Reproduction Service No: ED334339).

Darling-Hammond, L. (1985). Valuing of teachers: The making of a profession. Teachers College Record, 87, 205-218. 
Darling-Hammond, L. (1989). Accountability for professional practice. Teachers College Record, 91 (1), 59-80.

Darling-Hammond, L. (1990). Teacher professionalism: Why and how?. In A. Lieberman (Ed.), Schools as collaborative cultures: Creating the future now (pp. 25-50), Bristol, PA: Falmer Press.

Dinçer, B.; Akarsu, E. ve Yılmaz, S . (2016). The Investigation Of Perceptions Of Math Literacy Self-Efficacy And Mathematics Teaching Efficacy Belief Levels Of Preservice Primary Mathematics Teachers. Turkish Journal Of Computer And Mathematics Education (Turcomat), 7 (1), 207-228

Dinçer, Ö. (1998). Yerel yönetimlerin yeniden yapılandırılması ihtiyacı. D. Dursun, H. Al (Ed.), Türkiye'de yönetim geleneği, kurumlar, sorunlar ve yeniden yapılanma arayışları, İstanbul: İlke Yayınları.

EARGED [Eğitimi Araştırma ve Geliştirme Dairesi Başkanlığı]. (2003). Üçüncü Uluslararası Matematik ve Fen Bilgisi Çalışması (TIMSS1999)-Ulusal Rapor. Retrieved from http://egitek.meb.gov.tr/dosyalar\%5Cdokumanlar\%5Culuslararasi/timss_1999_ulusal_raporu.pdf

EARGED [Eğitimi Araştırma ve Geliştirme Dairesi Başkanlığı]. (2004). Öğrenci Başarısını Belirleme Programı (PISA-2003), Ulusal Rapor. Retrieved from http://egitek.meb.gov.tr/dosyalar/pisa/PISA_2003_Ulusal_Nihai.pdf

Ekici, G. (2014). Öğretmenin Öğrencilerin Akademik Başarı Ve Başarısızlığından Sorumluluk Algısı Konusunda Görüşler: Biyoloji Öğretmen Adayları Örneği. İlköğretim Online, 13(4), Pp: 1414-1448.

Erdoğan, Ç. ve Demirkasımoğlu, N. (2010). Teachers' And School Administrators' Views Of Parent Involvement İn Education Process. Kuram Ve Uygulamada Ĕ̆itim Yönetimi, 3 (3), 399-431.

Eryılmaz, B. (1997). Yerel yönetimlerin yeniden yapılandırılması, İstanbul: Birleşik Yayıncllık.

Frideman, I. (1999). Teacher Perceived Work Autonomy: The Concept And Its Measurement. Educatoinal And Psychological Measurement, 59 (1): 58-76

Fuhrman, S. H. (1999). The New Accountability-CPRE policy brief. Philadelphia, University of Pennsylvania, Consortium for Policy Research 
in Education. Retrieved from http://www.cpre.org/images/stories/cpre_pdfs/rb27.pdf

Gencel, İ. ve Özbaşı, D. (2014). Öğretmen Adaylarının Ölçme Ve Değerlendirme Alanına Yönelik Yeterlik Algılarının İncelenmesi. Elementary Education Online, 12 (1), 190-201.

Gökmenoğlu, T.; Beyazova, G. ve Kılıçoğlu, A. (2015). Mesleki Gelişim: Öğrenen Olarak Öğretmen Eğitimcileri. İlköğretim Online, 14(2).

Göksu, T. (2002). Türkiye' de yönetim anlayışı ve polis davranışı, H.H. Çevik ve T. Göksu (Eds.), Türkiye'de devlet, toplum ve polis, Ankara: Seçkin Yayınları, 69-90.

Gültekin, M., ve Çubukçu, Z. (2008). İlköğretim Öğretmenlerinin Hizmet İçi Eğitime İlişkin Görüşleri. Manas Üniversitesi Sosyal Bilimler Dergisi, 19, 185-201.

Hark Söylemez, A. ve Oral, D. (2014). Öğretmen Adaylarının Bilgisayara İlişkin Öz-Yeterlik Algılarının Çeşitli Değişkenler Açısından İncelenmesi. Bartin University Journal Of Faculty Of Education, 2 (1), 44-60.

Heim, M. (1995). Accountability in education: A primer for school leaders. HSLA Monograph. Pacific Resources for Education and Learning. Honolulu: HI.; Hawaii State Dept. of Education, Honolulu. (Eric Document Reproduction Service No: ED444267).

Hess, G. A., Jr. (1991). School restructuring Chicago style. Newbury Park, CA: Corwin.

Hill, P. (1996). The education consequences of choice. Phi Delta Kappan, 671-675.

Kantos, Z. E. (2010). Illköğretim okulu yönetici ve öğretmenlerinin görüşlerine göre kamu ve özel ilköğretim okullarn için bir hesap verebilirlik modeli (Yayınlanmamış doktora tezi). Ankara Üniversitesi, Ankara.

Kartal, S . (2008). İlk Ve Ortaöğretim Kurumlarında Velinin Okul Yönetimine Katılımı. Ahi Evran Üniversitesi Kırşehir Ĕ̆itim Fakültesi Dergisi, 9 (1), 23-30.

Kayabaş, Y. (2008). Öğretmenlerin Hizmet İçi Eğitimde Yetiştirilmesinin Önemi Ve Esasları. Türkiye Sosyal Araştırmalar Dergisi, 12(2), 932.

Kızıltaş, E. (2005). Bütçe hakkının kullanımında gelinen aşama: Doğrudan demokrasi. 20. Türkiye Maliye Sempozyumu Türkiye'de Yeniden Mali 
Yapılanma. Pamukkale Üniversitesi İktisadi ve İdari Bilimler Fakültesi, Maliye Bölümü (Yayın No:1).

Kline, P. (1994). An easy guide to factor analysis. New York, NY: Routledge. Koçak, E, Turan, S. ve Aydoğdu, E . (2012). Öğretmenlerin Yetki Devri, Otonomi Ve Hesap Verebilirliklerine İlişkin Görüşlerinin İncelenmesi. Eğitim Ve İnsani Bilimler Dergisi: Teori Ve Uygulama, (5), 117-148.

Kuchapski, R. P. (2001). Reconceptualizing accountability for education. (Doctoral dissertation), Retrieved from ProQuest Dissertations and Theses. (UMI No. NQ63889).

Leithwood, K. ve Earl, L. (2000). Educational accountability effects: An international perspective. Peabody Journal of Education, 75 (4), 1-18.

Levin, H. M. (1994). Education and workplace needs. Theory into Practice, 33(2), 132-137.

Mahony, P. ve Hextall, I. (2000) Reconstructing Teaching: standards, performance and accountability. London: Routledge.

McEwen, N. (1995). Accountability in education in Canada. Canadian Journal of Education, 20 (1), 1-17.

McNelis, R. H. (1998). The school improvement plan as a model for school-level accountability: An investigation of the Pittsburg public schools' planning requirements, (Doctoral dissertation) Retrieved from ProQuest Dissertations and Theses. (UMI No. 9906286).

Mete, F. ve Gürsoy, Ü. (2014). Yabancı Dil Olarak Türkçe Öğretiminde Öğretmen Yeterliklerine İlişkin Görüşler. Hacettepe Üniversitesi Eğitim Fakültesi Dergisi, 28 (28-3), 343-356

Mintrop, H. (2002). The limits of sanctions in low-performing schools: A study of Maryland and Kentucky schools on probation. Education Policy Analysis Archive, 11 (3), 1-30.

O'Day, J. (2002). Complexity, accountability and school improvement. Harvard Educational Review, 72 (3), 293-329.

Özaslan, G. (2015).Öğretmenlerin Sahip Oldukları Mesleki Özerklik Düzeyine İliğkin Algılar.Eğitimde Nitel Araştırmalar Dergisi Journal Of Qualitative Research İn Education, 3(2), 25- 39.

Özgen, K. (2016). Prımary Prospectıve Mathematıcs Teachers' SelfEfficacy Beliefs Towards Mathematical Literacy. Electronic Journal Of Education Sciences, 4 (7). 
Öztürk, M. ve Eroğlu, E . (2013). Coğrafya Öğretmen Yeterlikleri Ve Uygulamaların Değerlendirilmesi. Marmara Coğrafya Dergisi, 27, Pp: 630-659.

Parker, K. ve Leithwood, K. (2000). School councils' influence on school and classroom practice. Peabody Journal of Education, 75 (4), 37-65.

Ranson, S. (2003). Public accountability in the age of neoliberal governance. Journal of Education Policy, 18 (5), 459-480.

Rennie, K. M. (1997). Exploratory and confirmatory rotation strategies in exploratory factor analysis. (ERIC Document Reproduction Service No. ED406446).

Runhaar, P. (2008). Promoting Teachers' Professional Development. Doctoral Dissertation. Universiteit Twente, Enschede, Netherlands.

Saban, Y. ve Şeker, M. (2010). İlköğretim 5. Sınıf Öğrencilerinin Performans Görevlerindeki Başarıları İle Ailelerinin Eğitim-Öğretim Çalışmalarına Katılım Düzeyleri Arasındaki İlişkinin Belirlenmesi. Çukurova Üniversitesi Sosyal Bilimler Enstitüsü Dergisi, 19 (3), 361-390.

Sabancı, A. (1999). İlkögretim Okullarındaki Ödül Sisteminin Öğretmenler Ve Müdür Yardımcıları İçin Önem Derecesi, Gereksinimleri Karşılama Ve İş Doyumu Sağlama Düzeyi. Yayınlanmamış Doktora Tezi, Hacettepe Üniversitesi Sosyal Bilimler Enstitüsü, Ankara.

Seyhani, M.; Özder, H. ve Konedralı, G.(2009). An Evaluation Of The Reward-Punishment Policies Applied To Trnc Primary School Teachers. Kuram Ve Uygulamada Eğitim Yönetimi, 57 (57), 109-131.

Sezer, A.; Yıldırım, T. ve Pınar, A. (2012). Examination Of Computer SelfEfficacy Perceptions Of The Students Of Geography Education. Journal Of Education Faculty, 12 (2), 162-176.

Soydan, T. (2014). Eğitim Alanında Performans Değerlendirme Sisteminin Geçerliği Üzerine Yönetici Ve Öğretmen Görüşlerine Dayalı Bir Araştırma. Ege Eğitim Dergisi, 13 (1), 1-25.

Soydan, T.; Abalı, H. ve Kalsen, C. (2014). Eğitim Alanında Performans Değerlendirme Sistemine İlişkin Okul Yöneticilerinin Görüşleri. Journal of Education and Future, 6, 91-114 
Spencer, B. L. (2006). The will to accountability: Reforming education through standardized literacy testing. (Doctoral dissertation) Retrieved from ProQuest Dissertations and Theses. (UMI No. NR15947).

Stapleton, C. D. (1997). Basic concepts in exploratory factor analysis as a tool to evaluate score validity: A right-brained approach. (ERIC Document Reproduction Service No. ED407419).

Stecher, B. ve Kirby, N. (2004). Organizational improvement and accountability: Lessons for education from other sectors. Rand Cooporation. Retrieved from http://www.rand.org/content/dam/rand/pubs/monographs/2004/RAND_MG136.pdf

Stevens, J. (1996). Applied multivariate statistics for the social sciences. Mahwah, NJ: Lawrence Erlbaum.

Sumak, M. ve Roşan, Ş. (2015). Okul Temelli Yönetimin İlköğretim Okullarında Uygulanabilirliğine İlişkin Öğretmen Ve Yönetici Tutumlarının İncelenmesi (Gaziantep Örneği). Ahi Evran Üniversitesi Kırşehir Ĕ̆itim Fakültesi Dergisi, 7 (2), 317-334.

Şahin, M. ve Uysal, İ. (2014). Öğretmen Adaylarının Ölçme Ve Değerlendirme Konusundaki Öz-Yeterlik Algılarının İncelenmesi. Bartin University Journal Of Faculty Of Education, 2 (2), 190-207.

Şahin, S. ve Çeper, B. (2013). Study About The Effectiveness Of Primary Education Institutions' Standards. Elektronik Sosyal Bilimler Dergisi, 12 (46), 84-111.

Taşar, H . (2012). The Assessment Of Professional Competency Perception Of Teachers Working İn Primary Schools. Verimlilik Dergisi, 2012 (4), 67-77.

Too, D. R. (1989). Accountability in Hong Kong Secondary Education: The Attitudes of Principals and Vice-Principals in Anglican Schools, Master's Thesis, University Of Hong Kong, Hong Kong.

Turhan, M., Karabatak, S. ve Polat, M. (2014). Okullarda Örgütsel Öğrenme Engellerinin Vignette Tekniği İle İncelenmesi. Mersin Üniversitesi Eğitim Fakültesi Dergisi, 10 (1).

Türkyılmaz, M. ve Kuş, Z . (2010). Öğretmenlerin Okul Kalitesini Algılamalarındaki Farklılıklar. Ahi Evran Üniversitesi Kırşehir Eğitim Fakültesi Dergisi, 11 (2), 285-304. 
Uştu, H., Mentiş T. A. ve Sever, B.(2016). Öğretmenlerin Mesleki Gelişime Yönelik Algılarına İlişkin Nitel Bir Araştırma. Elektronik Mesleki Gelişim Ve Araştırmalar Dergisi, 4 (1), 82-104.

Üstünkal, F. T. (2013). Eğitim örgütlerinde performans değerlendirmenin öğretmenler üzerindeki etkisi. Yayımlanmamış Yüksek Lisans Tezi, Yeditepe Üniversitesi Sosyal Bilimler Enstitüsü, İstanbul.

Üzüm, P. ve Karslı, M. (2014). Awareness Levels Of Classroom Teachers About Teacher Authonomy (An Example Of The Province Of Izmir). İnönü Üniversitesi Eğitim Fakültesi Dergisi, 14 (3), 79-94.

Valli, L. ve Buese, D. (2007). The changing roles of teachers in an era of high-stakes accountability. American Educational Research Journal, 44, 519-558.

Wagner, R. B. (1989). Accountability in education: A philosophical inquiry. New York: Routledge.

Yaman, S. ve Karamustafaoğlu, S. (2011). Investigating Prospective Teachers' Perceived Levels Of Efficacy Towards Measurement And Evaluation. Ankara University Journal Of Faculty Of Educational Sciences, 44 (2), 53-72.

Yavuz, G. (2011). Öğretmen Adaylarının Öğrenme Öğretme Süreci Ve Ölçme Değerlendirme Alanındaki Yeterliklerine İlişkin Görüşleri. Yayınlanmamış Yüksek Lisans Tezi, Mersin Üniversitesi Eğitim Bilimleri Enstitüsü, Mersin.

Yeşil, R. (2009). Sosyal Bilgiler Aday Öğretmenlerinin Sınıfiçi Öğretim Yeterlikleri (Kırşehir Örneği). Türk Eğitim Bilimleri Dergisi, 7 (1), 23-48.

\section{Kaynakça Bilgisi / Citation Information}

Erdağ, C. ve Karadağ E. (2017). Öğretmenler ve okul müdürleri perspektifinden okul hesap verebilirliği politikaları. OPUS - Uluslararası Toplum Araştırmaları Dergisi, 7(13), 459-496. 